\title{
Are Passive Index Funds Active Owners? Corporate Governance Consequences of Passive Investing
}

\author{
GIOVANNI STRAMPELLI*
}

\section{TABLE OF CONTENTS}

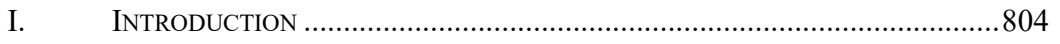

II. The Rise OF PASSIVE INVESTING IN THE UNITED STATES AND THE EU ......809

III. The CORPORATE GOVERNANCE IMPLICATIONS OF PASSIVE INVESTING: From SHORT-TERMISM to PERMANENT SHAREHOLDERS .........................814

A. The Passive Investors' Cost-Driven Approach to

Voting and Engagement ............................................................814

B. Indirect Corporate Governance Consequences of Passive Investing: The Impact on Activism...

IV. RECONSIDERING THE APPROACH TO INSTITUTIONAL INVESTOR ENGagement In THE ERA OF PASSIVE INVESTING: THE KeY Problem is One of Costs, Not Short-Termism

V. ACTIVATing Passive InVEStors by Reducing ENGagementRELATED COSTS: A CONCEPTUAL FRAMEWORK FOR Potential REgUlatory StRATEGIES.....

A. Setting a More Favorable Legal Environment for Activist Investors

B. Eliminating Passive Fund Voting to Activate Other

Nonactivist Institutional Investors?

C. Shifting Passive Funds' Engagement Costs to Ultimate Investors of Investee Companies

D. Redistributing Engagement Costs by Favoring Institutional Investor Coordination

VI. CONCLUSION 851 University, Milan.

(C) 2018 Giovanni Strampelli. Associate Professor of Business Law, Bocconi 


\section{INTRODUCTION}

The popularity of index funds, which automatically track an index of stocks, continues to grow in the United States and, albeit less intensely, in the European Union (EU). "Investors have embraced the new model of low-cost, passive investing and [continue to turn] away from high-cost active funds." 2 Due to the high concentration of the index funds industry, the exponential rise of mutual funds designed to track stock indices has had significant corporate governance implications. ${ }^{3}$ Specifically, passive investing significantly impacts listed companies' ownership on both sides of the Atlantic. The three leading passive fund managers - BlackRock, Vanguard, and State Street - make up an increasingly important component of the shareholder base of listed companies, as they hold relevant stakes - usually not exceeding 5\% -in thousands of American and European companies. ${ }^{4}$ Therefore, they are able to play a crucial role in shareholders' meetings and to exert considerable influence over the board and management.

Although it is widely acknowledged that the rise of passive investing is beneficial for final investors - "who benefit from greater diversification and lower costs" - many institutions and corporate governance experts contend the "ETF-ization" of listed company ownership has negative corporate governance implications because passive investors are deemed to be also passive owners, who are not interested in being actively involved in the corporate governance of investee companies. ${ }^{7}$

There is no doubt that institutional investors' corporate governance passivity, or rational reticence, is nothing new. As Ronald Gilson and Jeffrey Gordon note, institutional investors are "rationally reticent," as they respond to proposals by other investors, but are unlikely themselves

1. See infra Part II.

2. Timothy Strauts, 5 Charts on U.S. Fund Flows that Show the Shift to Passive Investing, MORNINGSTAR (Mar. 12, 2018), https://www.morningstar.com/blog/2018/03/ 12/fund-flows-charts.html [https://perma.cc/JPC5-Q5PK].

3. See, e.g., Lucian A. Bebchuk et al., The Agency Problems of Institutional Investors, 31 J. ECON. PersP. 89, 100-01 (2017); Jill Fisch et al., Passive Investors 1, 14, 16, 19 (Univ. of Penn. Inst. for Law \& Econ., Working Paper No. 414/2018).

4. See infra Part II.

5. Dorothy S. Lund, The Case Against Passive Shareholder Voting, 43 J. CoRP. L. 493, 494 (2018); see also Frank Partnoy, Are Index Funds Evil?, Atlantic, Sept. 2017, at 24, 24.

6. Peter Smith, The ETF-isation of the S\&P 500 Sparks Lively Debate, FIN. TIMES (July 10, 2017), https://www.ft.com/content/2d81240c-626c-11e7-91a7-502f7ee26895 (referencing the report, The ETF-ization of the S\&P 500, Part 1, from Bank of America Merrill Lynch).

7. See infra Part III. 
to make them. ${ }^{8}$ Although the rational reticence of institutional investors may be attributable to a variety of factors, the fundamental problem is that they are not adequately incentivized to engage actively with investee companies. $^{9}$ The costs incurred in relation to engagement reduce returns and can result in a loss of clients to competitors offering higher returns. Furthermore, there is an acute free riding problem: the costs incurred by an institutional investor to engage with an investee company also benefit the other institutional investors in the same company. ${ }^{10}$

The dissemination of passive investing seems to exacerbate the rational reticence of institutional investors. Even though index funds are, by definition, focused on the long term - they are designed to automatically track a market index and are unable to sell the shares included in the tracked index - index fund managers are deemed to have even more limited incentives to engage with investee companies than with other institutional investors. ${ }^{11}$ For passive funds, the potential downsides of engagement are greater than they are for actively managed funds because, in the passive fund industry, the free rider problem is even more significant. ${ }^{12}$ As passive funds automatically track an index, for example S\&P 500, the potential benefits resulting from corporate governance intervention are very limitedgiven the huge number of portfolio companies - and inevitably create an advantage for all competitors tracking the same index. ${ }^{13}$ Consequently, passive institutional investors tend to invest limited resources in engaging with investee companies. ${ }^{14}$ In addition, although they vote in almost all

8. Ronald J. Gilson \& Jeffrey N. Gordon, The Agency Costs of Agency Capitalism: Activist Investors and the Revaluation of Governance Rights, 113 COLUM. L. REV. 863, 895 (2013).

9. See Edward B. Rock, Institutional Investors in Corporate Governance, in THE OXFORD HANDBOOK OF CORPORATE LAW AND GOVERNANCE 364, 371-74 (Jeffrey Gordon \& Wolf-Georg Ringe eds., 2018).

10. See id. at 373.

11. See F. William McNabb III, Getting to Know You: The Case for Significant Shareholder Engagement, HARV. L. SCH. F. ON CORP. GOVERnANCE \& Fin. REG. (June 24, 2015), https://corpgov.law.harvard.edu/2015/06/24/getting-to-know-you-the-case-for-significantshareholder-engagement/ [https://perma.cc/A6SQ-A5K6] ("[W]e are permanent shareholders. To borrow a phrase from Warren Buffet: Our favorite holding period is forever. We're going to hold your stock when you hit your quarterly earnings target. And we'll hold it when you don't. We're going to hold your stock if we like you. And if we don't. We're going to hold your stock when everyone else is piling in. And when everyone else is running for the exits. . . . That is precisely why we care so much about good governance.").

12. See infra Part III

13. See infra Part III.

14. See infra Part III. 
shareholder meetings of the investee companies and have a high number of engagements, leading passive fund managers often use a one-size-fitsall approach, which does not analyze the specific problems relating to individual companies. ${ }^{15}$ Therefore, the rise of passive investing seems to clash with the aim - pursued by many lawmakers and regulators - of promoting more active involvement by institutional investors in the corporate governance of their investee companies and of calling for a reconsideration of the role of institutional investors in the governance of listed companies.

This proves to be particularly apparent within the EU corporate governance framework where "[e]ffective, sustainable shareholder engagement is one of the cornerstones of listed companies' corporate governance model, which depends inter alia on checks and balances between the different organs and different stakeholders," asked to "play an important role in the corporate governance of those companies, but also more generally with regard to their strategy and longterm performance." 17

Nevertheless, the EU Commission contends that institutional investors focus mainly on the short-term horizon and seek short-term profits ${ }^{18}$ and, consequently, puts companies under pressure and pushes them to adopt short-term oriented strategies. ${ }^{19}$ Therefore, corporate governance initiatives at European and EU Member State levels seek to incentivize institutional investors and asset managers to shift their focus to the medium and longterm and to stimulate their engagement to promote review of investee companies by institutional investors. ${ }^{20}$ At the EU level, the SHRD, as modified by the SHRD II, sets out specific requirements to encourage

15. See infra Part III.

16. Eur. Comm'n, Action Plan: European Company Law and Corporate Governancea Modern Legal Framework for More Engaged Shareholders and Sustainable Companies, at 8, COM (2012) 740 final (Dec. 12, 2012).

17. Directive 2017/828, of the European Parliament and of the Council of 17 May 2017 amending Directive 2007/36/EC as Regards the Encouragement of Long-Term Shareholder Engagement, 2017 O.J. (L 132) 1, 3 [hereinafter SHRD II].

18. Id. at 1; see also Therese Strand, Short-Termism in the European Union, 22 Colum. J. Eur. L. 15, 23-25 (2015).

19. See Rock, supra note 9, at 363 ("[C]apital markets often exert pressure on companies to perform in the short term, which may jeopardize the long-term financial and nonfinancial performance of companies and may, among other negative consequences, lead to a suboptimal level of investments, for example in research and development, to the detriment of the long-term performance of both the companies and the investors." (citing SHRD II, supra note 17, at 3)); see also Klaus J. Hopt, Corporate Governance in Europe: A Critical Review of the European Commission's Initiatives on Corporate Law and Corporate Governance, 12 N.Y.U. J.L. \& Bus. 139, 173 (2015).

20. See SHRD II, supra note 17, at 5, 16. 
long-term oriented shareholder engagement. ${ }^{21}$ In addition, Directive 2013/50/EU—amending the Transparency Directive - removed the duty to prepare quarterly financial reports, which have been blamed as one of the drivers of the short term focus of investors and companies. ${ }^{22}$ What is more, over the last few years, many Member States have taken steps to incentivize long-term investment by institutional investors, such as the introduction of time-phased voting in France and Italy. ${ }^{23}$ This legislation has also been complemented by soft law measures. In particular, stewardship codes drawn up by institutions and sectoral associations at the national level, according to the leading example of the EFAMA Stewardship Code, seek to promote ongoing interaction between institutional investors and investee companies to protect value over the long-term. ${ }^{24}$

However, the conceptual background to such initiatives is not entirely convincing. First, a large body of scholarship denies that short-termism is a major problem for modern corporations. ${ }^{25}$ A large number of studies demonstrate that, in recent years, there has not been any significant reduction in the investment timeframe for institutional investors. ${ }^{26}$ Empirical evidence also shows that short-termism is not necessarily bad and does not necessarily

21. See generally Directive 2007/36, of the European Parliament and of the Council of 11 July 2007 on the Exercise of Certain Rights of Shareholders in Listed Companies, 2007 O.J. (L 184) 17 [hereinafter SHRD].

22. See generally Directive 2013/50, of the European Parliament and of the Council of 22 October 2013 amending Directive 2004/109/EC of the European Parliament and of the Council on the Harmonisation of Transparency Requirements in Relation to Information about Issuers Whose Securities Are Admitted to Trading on a Regulated Market, Directive 2003/71/EC of the European Parliament and of the Council on the Prospectus to be Published when Securities are Offered to the Public or Admitted to Trading and Commission Directive 2007/14/EC Laying Down Detailed Rules for the Implementation of Certain Provisions of Directive 2004/109/EC, 2013 O.J. (L 294) 13, 19.

23. See Hopt, supra note 19, at 173-74; Marco Ventoruzzo, The Disappearing Taboo of Multiple Voting Shares: Regulatory Responses to the Migration of Chrysler-Fiat 1, 8-9 (European Corp. Governance Inst., Working Paper No. 288/2015, 2015), http://www. ecgi.global/sites/default/files/working_papers/documents/SSRN-id2574236.pdf [https:// perma.cc/5C7J-8S88].

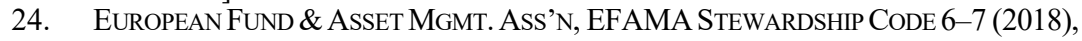
http://www.efama.org/search/pages/results.aspx/results.aspx?sq=1\&k=Code $\% 20$ For $\% 20$ External\%20Governance [https://perma.cc/WHL3-KUWY].

25. See Strand, supra note 18, at 23-29.

26. See generally Anne M. Tucker, The Long and the Short: Portfolio Turnover Ratios \& Mutual Fund Investment Time Horizons, 43 J. CoRP. L. 581 (2018) (showing that mutual fund investment time horizons, as measured by portfolio turnover ratios, did not decline between 2005-2015). 
affect long-term investments and performance. ${ }^{27}$ In addition, the EU Commission's institutional investor-driven strategy is subject to a further limit. It considers institutional investors in unitary terms and does not take sufficient account of the fact that they have different investment styles. ${ }^{28}$ Because index funds are unable to sell shares included in the tracked index and, consequently, are long-term shareholders, regulatory strategies aimed at curbing short-termism are completely ineffective in turning passive investors into active owners. ${ }^{29}$ By contrast, the rise of passive investing shows that, to this end, reducing the engagement-related costs is key. ${ }^{30}$

Against this background, although the corporate governance consequences of passive investing have already gained much attention - albeit still limited on the part of legal scholarship - in the United States and around the world, this Article attempts to consider the lessons that can be learned from the EU Corporate governance approach, which largely relies on the active role of institutional investors. ${ }^{31}$ The objective is to develop a new policy framework that can not only effectively promote a more active corporate governance role for passive investors but also can be easily transplanted into various countries, including the United States, when considering alternatives to hedge fund-driven activism.

To achieve this aim, this Article proceeds as follows. Part II describes passive investing and its vertiginous rise in the United States. It also provides an overview of the factors that can lead to further expansion of passive funds in the EU. Part III presents a survey of empirical and anecdotal evidence concerning the corporate governance consequences of passive

27. See, e.g., Jesse M. Fried, The Uneasy Case for Favoring Long-Term Shareholders, 124 YALE L.J. 1554, 1554 (2015) ("Favoring the interests of long-term shareholders could thus reduce, rather than increase, the value generated by a firm over time."); Mark J. Roe, Corporate Short-Termism - In the Boardroom and in the Courtroom, 68 BUS. LAw. 977, 978 (2013) ("[S]ystem-wide short-termism in public firms is something to watch for carefully, but not something that today should affect corporate lawmaking."). But see generally Lynne L. Dallas, Short-Termism, the Financial Crisis, and Corporate Governance, 37 J. CORP. L. 265 (2012) (proposing structural changes to counter short-termism). See also

Short-Horizon Investors 27 (European Corp. Governance Inst., Working Paper No. 467/2016, 2018), https://ssrn.com/abstract=2723357 [https://perma.cc/8ZC4-QYNG] ("[I]n the aftermath of permanent negative shocks that alter a firm's economic environment and require changes in business strategy, the managers of firms with more short-horizon investors do not enjoy the quiet life and adapt to the new business environment better than other

28. Marina B. Madsen, Promoting the 'Right' Kind of Ownership: The Good, the Bad and the Passive, 29 EuR. Bus. L. REV. 143, 149-50 (2018).

29. See infra Section V.C.

30. See infra Part IV.

31. See SHRD II, supra note 17, at 3. 
investing. Part IV evaluates whether the current EU Commission corporate governance approach and, in particular, the disclosure duties set out by the SHRD II, are capable of turning passive investors into active owners. In doing so, Part IV also contends the main obstacle to active institutional investors' involvement in the governance of investee companies is not short-termism but rather the costs of engagement. Part V develops a conceptual framework of potential regulatory strategies aimed at stimulating more active involvement by passive investors by favoring a reduction in engagementrelated costs. Part VI sets out concluding remarks.

\section{THE RISE OF PASSIVE INVESTING IN THE UNITED STATES AND THE EU}

Passive index funds include index mutual funds and exchange traded funds (ETFs) ${ }^{32}$ Although index mutual funds and ETFs are technically different - index funds are traded only once a day after markets have closed and ETFs can be bought and sold continuously during the entire trading day ${ }^{33}$ - they share the fundamental characteristic of seeking to replicate stock indices and to minimize cost ratios. ${ }^{34}$ Therefore, as passive funds attract investors on the basis of their ability to track an index and do not seek outperformance as active investors do, their investing "decisions are largely automated" and do not imply a specific analysis to pick new shares. ${ }^{35}$ Consequently, passive funds can charge much lower fees than active funds. ${ }^{36}$

32. Hereinafter, passive index funds, passive funds, and index funds are used as synonyms. When a distinction between these definitions is relevant, it will be specified.

33. Benjamin Braun, From Performativity to Political Economy: Index Investing, ETFs and Asset Manager Capitalism, 21 NEw POL. ECON. 257, 266 (2016).

34. Jan Fichtner et al., Hidden Power of the Big Three? Passive Index Funds, ReConcentration of Corporate Ownership, and New Financial Risk, 19 BUS. \& POL. 298, 299 (2017); see also Edwin J. Elton et Al., Passive Mutual Funds And ETFs: PERFORMANCE AND COMPARISON 3-6 (2018). Index mutual funds and ETFs can be considered substitutes, but "not perfect substitutes." Anna Agapova, Conventional Mutual Index Funds Versus Exchange Traded Funds, 14 J. Fin. MKT. 323, 224 (2011).

35. Lund, supra note 5, at 506, 511.

36. See also Fin. Conduct Auth., Asset Management Market Study Final REPORT 5 (2017), https://www.fca.org.uk/publication/market-studies/ms15-2-3.pdf [https:// perma.cc/97A3-58ZX] ("[M]any active funds offer similar exposure to passive funds, but some charge significantly more for this. We estimate that there is around $£ 109 \mathrm{bn}$ in 'active' funds that closely mirror the market which are significantly more expensive than passive funds."). 
Over the last few years, such a favorable cost structure and the incapacity of a large proportion of active managed funds to beat the market indices has led to an exponential rise in passive investing in the United States. ${ }^{37}$ To cite some particularly meaningful data regarding only equity funds, index funds hold a market share of $43 \%$ in the United States. ${ }^{38}$ At the end of 2015, passive index funds in the United States had about $\$ 4$ trillion in assets under management, exceeding the assets under management of the entire hedge fund industry. ${ }^{39}$ Moreover, over the past ten years the share of total U.S. market capitalization held by passive index "funds has quadrupled to more than $8 \%$, or $12 \%$ of the S\&P 500." 40 Additionally, growth in passive index funds is likely to continue into the future. In fact, in January 2018, assets held globally by passive index funds passed the $\$ 5$ trillion mark for the first time; experts expect that it will soon reach the $\$ 10$ trillion mark $^{41}$ and even outpace active fund assets in the United States by $2024 .^{42}$

Despite its continuous growth, the passive index fund industry remains highly concentrated. The market is dominated by Blackrock, Vanguard and State Street Global Advisors (State Street) - the "Big Three"-which, overall, manage over $90 \%$ of all assets under management in passive

37. See Itzhak Ben-David et al., Exchange-Traded Funds, 9 AnN. REv. Fin. Econ. 169, 175 (2017); Fichtner et al., supra note 34, at 302-03; see also Jeff Bukhari, StockPicking Fund Managers Are Even Worse Than We Thought at Beating the Market, FORTUNE (Apr. 13, 2017), http://fortune.com/2017/04/13/stock-indexes-beat-mutual-funds/ [https://perma.cc/32KH-ULJB] ("The S\&P 500 outperformed more than $92 \%$ of large-cap funds over the last 15 years. Mid- and small-cap funds fared no better over the time period, with their benchmarks besting them $95.4 \%$ and $93.2 \%$ of the time, respectively. Overall, $82.2 \%$ of all active funds were outperformed over the 15-year period."); Attracta Mooney, European Active Managers Beaten by Passives, 10-Year Study Finds, FIN. TIMES (Sept. 30, 2018), https://www.ft.com/content/c6183f2f-f58a-3569-a6ac-9d2b44adfe28 ("Most active fund managers survived and beat their average passive peers in just two of the 49 fund categories, according to an analysis by Morningstar, the data provider, covering June 2008 to June 2018.").

38. Hortense Bioy et Al., Morningstar, Passive Fund Providers TaKe an ACtive APPROACH TO INVESTMENT STEWARDSHIP 8 (2017), http://www.morningstar.com/content/ dam/morningstar-corporate/pdfs/Research/Morningstar-Passive-Active-Stewardship.pdf [https://perma.cc/VA89-4CYP].

39. Id. at 6-8.

40. Lund, supra note 5, at 507 (citing Ian Appel et al., Passive Investors, Not Passive Owners, 121 J. FIN. ECON. 111, 111 (2016)).

41. Chris Flood, ETF Market Smashes Through \$5tn Barrier After Record Month, Fin. TIMES (Feb. 10, 2018), https://www.ft.com/content/5cf7237e-0cdc-11e8-839d-41ca $06376 \mathrm{bf} 2$.

42. See Trevor Hunnicutt, Index Funds to Surpass Active Fund Assets in U.S. by 2024: Moody's, REUTERS (Feb. 2, 2017, 6:31 AM), https://www.reuters.com/article/usfunds-passive/index-funds-to-surpass-active-fund-assets-in-u-s-by-2024-moodys-idUSKB N15H1PN [https://perma.cc/Q3KH-Y4DW]. 
equity funds. ${ }^{43}$ Such a high concentration of the passive index fund industry has contributed to the re-concentration of listed company ownership in the United States. For example, Blackrock has a 5\% stake in at least 2,000 out of about 3,900 listed companies in the United States.; similarly, Vanguard has 1,900 5\% blockholdings. ${ }^{44}$ The 5\% blockholdings of Blackrock and Vanguard are much more numerous than those of the world's largest actively managed fund group, Fidelity Investments, which holds about 700 5\% holdings in the United States. ${ }^{45}$ Considering the size of their equity interests, the Big Three together represent the largest shareholder in most U.S. listed companies; in particular, they own nearly $90 \%$ of public companies in the S\&P 500 and at least $40 \%$ of all U.S. listed companies. ${ }^{46}$

Passive index funds have also experienced significant growth in Europe, albeit not comparable to U.S. growth. At the end of 2017, passive index funds accounted for $16 \%$ of total assets under management, although the figure ten years ago was $7 \% .{ }^{47}$ The different growth rate for passive index funds in the United States and in the EU may be dependent upon the different client base. Although in the United States the growth of passive investing has been pushed by both institutional and retail investors, in the EU prevalently institutional investors have invested in passive funds. ${ }^{48}$ Nevertheless, the EU has also experienced significant growth in the

43. Fichtner et al., supra note 34 , at 304.

44. Id. at $311-12$.

45. Id. at $312-13$.

46. Id. at 313 ("'L]arge companies where the Big Three are not the main shareholders are typically dominated by private individuals [including:] Berkshire Hathaway (Warren Buffett) [and] Amazon.com (Jeff Bezos) ... ..”); Martin C. Schmalz, Common-Ownership Concentration and Corporate Conduct, 10 AnN. REv. FIn. ECON. 413, 416-17 (2018).

47. BIOY ET AL., supra note 38, at 6.

48. Id. ("Fund distribution networks in Europe are dominated by large commercial banks that have shown little interest in the commercialization of low-cost investments to retail investors. Besides, up until now, European financial advisors had never been incentivized to promote funds such as ETFs that do not pay retrocession fees."); see also Philip Stafford, The Differences Between US and European ETF Markets, FIN. TIMES (Dec. 7, 2016), https://www.ft.com/content/aa4e3be2-baff-11e6-8b45-b8b81dd5d080. Moreover, the prevalence of institutional investors among clients of passive funds is consistent with the general trend in the European asset management industry, where pension funds, insurance companies, and other institutional investors are by far the most important clients. See EuROPEAN Fund \& ASSET MGMT. Ass'N, ASSET MANAGEMENT INEUROPE 29-33 (9th ed. 2017), https://www.efama.org/Publications/Statistics/Asset $\% 20$ Management\%20Report/Asset $\%$ 20Management\%20Report\%202017.pdf [https://perma.cc/YC6Q-Y3XZ]. 
market share of passive funds over the last few years. ${ }^{49}$ In 2017, "[n]et inflows into European-listed ETFs reached a record \$108 [billion]." 50

This favorable trend is expected to be bolstered by recent regulatory changes affecting EU financial markets - including the implementation of the Markets in Financial Instruments Directive (MiFID II) - which introduces some changes in the law that could favor the dissemination of passive index funds and specifically ETFs. ${ }^{51}$ First, MiFID II leads to an increased transparency of ETF trading. ${ }^{52}$ Because ETF trades in Europe mainly occurred in private bilateral over-the-counter transactions, most ETF trades were unreported. ${ }^{53}$ The MiFID II radically changes this scenario by subjecting trades in ETFs to a post-trade reporting requirement. ${ }^{54}$ Therefore, experts believe the visibility of trading volumes will enable investors to better understand the true level of trading and liquidity and, consequently, attract more investor inflows into ETFs. ${ }^{55}$ Second, to strengthen investor protection and to increase clarity for clients regarding the service they receive, the MiFID II restricts the ability for firms providing independent investment advice and portfolio management services to accept and retain fees, commissions, or any monetary and nonmonetary benefits from issuers or product providers. ${ }^{56}$ Such a restriction on commissions "is expected to create a level-playing field for the distribution of passive funds to European retail investors" by stimulating financial advisors to promote passive index funds more intensively. ${ }^{57}$

Nevertheless, although their market share in the EU has been hitherto much more limited than in the United States, passive index funds have already had a significant impact on the corporate governance of many European investee companies. For instance, Blackrock is currently "the largest shareholder of a third of FTSE 100 companies as well as a top-5 shareholder of 89 of them [and] the largest shareholder in around one-

49. BIOY ET AL., supra note 38, at 6.

50. Chris Flood, Mifid Tips Balance Against Active Funds in Favour of ETFs, FIN. TIMES (Feb. 4, 2018), https://www.ft.com/content/07f1d252-0061-11e8-9e12-af73e8db3c71.

51. See Directive 2014/65, of the European Parliament and of the Council of 15

014 on Markets in Financial Instruments and Amending Directive 2002/92/EC and Directive 2011/61/EU, 2014 O.J. (L 173) 349, 349 [hereinafter MiFID II].

52. See id. at 401.

53. Flood, supra note 50.

54. See MiFID II, supra note 51, at 401-02.

55. See Flood, supra note 50.

56. See MiFID II, supra note 51, 405-08.

57. BIOY ET AL., supra note 38, at 6-7. But see Pauline Skypala, EU Rule Changes Deliver Mixed Results So Far, Fin. TIMES (Sept. 9, 2018), https://www.ft.com/content/ 46641 e26-93f2-11e8-95f8-8640db9060a7 ("[C]hange will come slowly in Europe as retail investors there are mainly served by banks rather than independent financial advisers."). 
third of DAX-30 companies." 58 The position is similar for French and Italian listed companies. An analysis recently issued by Euronext shows that, at the end of 2016, Blackrock and Vanguard were, respectively, the fourth and fifth largest shareholders in the CAC 40 and that passive funds accounted for more than 5\% of shareholdings in twenty-nine CAC 40 companies. ${ }^{59}$ Along the same lines, in Italy, Blackrock and Vanguard are respectively the first and third largest foreign investors on the Milan Stock Exchange in terms of the size of their holdings ${ }^{60}$ BlackRock has holdings in excess of $2 \%$ in twenty-five out of the forty companies included in the FTSE MIB index. ${ }^{61}$

Therefore, even though their growth has been more restrained in the EU than in the United States, passive index funds are already a force to be reckoned with for European lawmakers, regulators, and corporate governance experts. As shown below, ${ }^{62}$ the growth in long term oriented investors, who adopt a passive investment style, calls for a reconsideration of the EU Commission's strategy, which is largely reliant on the role of institutional investors and seeks to turn them into active stewards of investee companies.

58. See Schmalz, supra note 46 , at $15-16$

59. See generally EuroneXt, Who ARE THE CAC 40 Shareholders? (2018), http://www.agefi.fr/sites/agefi.fr/files/fichiers/2018/01/euronext_cac_40_study_en.pdf [https://perma.cc/PFB7-RJS5].

60. Andrea Franceschi, Da Blackrock a Norges Bank, ecco chi sono i più importanti investitori esteri a Piazza Affari [From BlackRock to Norges Bank, Here Are the Most Important Foreign Investors at Piazza Affari], ILsOLe24ORE (Sept. 10, 2015, 2:54 PM) (It.), http:/www.ilsole24ore.com/art/finanza-e-mercati/2013-12-20/la-top-five-investitoriesteri-piazza-affari-blackrock-105606.shtml?uuid=AB4CrEl\#navigation [https://perma.cc/ SJ7W-FFE8].

61. Id.

62. See infra Parts IV, V. 


\section{THE CORPORATE GOVERNANCE IMPLICATIONS OF PASSIVE \\ INVESTING: FROM SHORT-TERMISM TO PERMANENT SHAREHOLDERS}

\section{A. The Passive Investors' Cost-Driven Approach to Voting and Engagement}

Because of its significant growth, numerous studies have examined passive investing from various perspectives. ${ }^{63}$ The legal literature has until now mainly focused on potential anticompetitive effects that can arise when - as frequently occurs-leading passive investors, meaning generally the Big Three, own large shareholdings in competing companies. ${ }^{64}$ Over the last few years, scholars have also been considering

63. Lund, supra note 5, at 496. See generally Henry T. C. Hu \& John D. Morley, A Regulatory Framework for Exchange-Traded Funds, 91 S. CAL. L. REV. 839 (2018) (showing the need for a regulatory framework for ETFs).

64. Compare Einer Elhauge, Horizontal Shareholding, 129 HARV. L. REV. 1267, 1267 (2016) ("A small group of institutions has acquired large shareholdings in horizontal competitors throughout our economy, causing them to compete less vigorously with each other."), and Fiona Scott Morton \& Herbert Hovenkamp, Horizontal Shareholding and Antitrust Policy, 127 YALE L.J. 2026, 2027-28 (2018) ("[T]o the extent the empirical evidence warrants the conclusion that large scale horizontal acquisitions threaten reduces product output and higher prices, the existing tools of antitrust merger enforcement are sufficient to support challenges to those acquisitions."), and Eric A. Posner et al., $A$ Proposal to Limit the Anticompetitive Power of Institutional Investors, 81 ANTITRUST L.J. 669, 669-700 (2016) ("Antitrust scholars have long understood that when one owner ... acquires large stakes in two or more competitors, it will have an incentive to induce those competitors to compete less. Recent empirical evidence shows that this type of concentration is . . l leading to higher prices."), with Thomas A. Lambert \& Michael E. Sykuta, The Case for Doing Nothing About Institutional Investors' Common Ownership of Small Stakes in Competing Firms 2-3 (Univ. of Mo. Sch. of Law Legal Studies Research. Paper Series, Research Paper No. 2018-21, 2018) ("The prevailing view among the antitrust elite... seems to be (1) that common holdings by institutional investors significantly diminish competition in oligopolistic industries, and (2) that additional antitrust intervention is appropriate to prevent competitive harm. We are skeptical of this two-pronged view."), and Edward B. Rock \& Daniel L. Rubinfeld, Defusing the Antitrust Threat to Institutional Investor Involvement in Corporate Governance 1-2 (N.Y. Univ. Law \& Econ. Research Paper Series, Working Paper No. 17-05, 2017) (“[E]ven if there were substantial antitrust risk, the primary effect of [proposals for dramatic changes in enforcement policy] would be to drive institutional investors back towards their traditional passivity in corporate governance ...."). See also Asaf Eckstein, The Virtue of Common Ownership in an Era of Corporate Compliance 54 (June 12, 2018) (unpublished manuscript) (on file with author) ("[C]ommon ownership has the potential to enhance institutional investor's incentives to improve their awareness of macro legal risks - risks of criminal investigations and criminal and civil proceedings that are common to entire industries such as healthcare (pharmaceuticals), finance and energy - and to respond appropriately. It also demonstrates how common ownership is likely to improve the ability of institutional investors to recognize new trends and patterns by having privileged access to rulemaking and by creating a network of companies that have similar legal exposure and that allow experimental learning."). 
the impact of passive investing, especially of ETFs on market efficiency. In particular, the rise of passive investing is deemed to pose a threat to price discovery and to lead to an increased procyclicality of markets. ${ }^{65}$ Recently, legal and financial scholars have started to shed light on the corporate governance implications of passive investing; ${ }^{66}$ however, this stream of research is in the initial stages. ${ }^{67}$

As far as the corporate governance implications of passive investing are concerned, the fundamental question is whether passive investors are also passive owners, or whether they can play an active role in the corporate governance of investee companies. On the one hand, as passive index funds seek to replicate stock indices and to minimize cost ratios, they do not have financial incentives to intervene in the corporate governance of their portfolio companies. ${ }^{68}$ Because the indices replicated by index funds include hundreds of companies, the potential benefits deriving from corporate governance intervention are likely to have a very limited impact on the funds' overall performance. ${ }^{69}$ In addition, index fund managers are affected by a structural collective action problem because, as Bebchuk, Cohen, and Hirst note, "a move by any given index fund manager to improve stewardship and raise fees would unravel, because its investors would prefer to free-ride on the investment manager's efforts by switching to another investment fund that offers the same indexed portfolio but without stewardship or higher fees." ${ }^{, 70}$ Therefore, according to this line of thought, passive investing strategies exacerbate the collective action problems facing institutional investors, with the sole exception of hedge funds. ${ }^{71}$

65. See Steven D. Bleiberg ET AL., The Impact OF PAssive InVesting On Market EFFICIENCY 7 (2017), https://bpmmagazine.com/wp-content/uploads/2017/05/The_Impact_of Passive Investing_FINAL.pdf [https://perma.cc/36SJ-9MZB]; Ben-David et al., supra note 37, at 178-85; Vladyslav Sushko \& Grant Turner, The Implications of Passive Investing for Securities Markets, BANK INT'L SETTLEMENTS Q. REV., Mar. 2018, at 113, 119-26; Itzhak Ben-David et al., Do ETFs Increase Volatility? 43 (Fisher Coll. of Bus. Working Paper Series, Working Paper No. 2011-03-20, 2017).

66. See, e.g., BIOY ET AL., supra note 38, at 3; Lund, supra note 5, at 527-28.

67. See Nan Qin \& Di Wang, Are Passive Investors a Challenge to Corporate Governance? 2 (Mar. 24, 2018) (unpublished manuscript) (on file with author) ("[T]he potential impact of passive investors on corporate governance is an important but largely unexplored topic.").

68. Lund, supra note 5, at 500.

69. See id.

70. Bebchuk et al., supra note 3, at 98.

71. See infra text accompanying notes 133-33. But see Fisch et al., supra note 3, at 1, 10-13 ("While the conventional view focuses on the competition between passive 
What is more, the ability of passive investors to effectively oversee investee companies is considered limited because they do not have the ability to influence mangers by threatening to withdraw from the company. ${ }^{72}$

On the other hand, however, there are several reasons why passive index funds could play an active role in the governance of investee companies. ${ }^{73}$ First, because passive investors are, by definition, permanent shareholders, they should naturally be incentivized to monitor managers to improve the company's performance. ${ }^{74}$ Second, because the Big Three "are simply too-big-to-be-passive," $" 75$ there is growing reputational and regulatory pressure for leading passive index fund managers to play an active monitoring role. ${ }^{76}$ On both sides of the Atlantic, the U.S. Securities and Exchange Commission $(\mathrm{SEC})^{77}$ and the EU Commission adopted a disclosure-based regulatory

funds tracking the same index, our analysis suggests that passive funds also compete against active funds. Passive fund sponsors therefore have an incentive to take measures to neutralize the comparative advantage enjoyed by active funds, that is, their ability to use their investment discretion to generate alpha. Because they cannot compete by exiting underperforming companies, passive investors must compete by using 'voice' to prevent asset outflow.”).

72. See Appel et al., supra note 40, at 113-14.

73. See Fisch et al., supra note 3, at 15-16.

74. See Appel et al., supra note 40, at 113-14; see also BIOY ET AL., supra note 38, at 3; Qin \& Wang, supra note 67, at 3; Zohar Goshen \& Sharon Hannes, The Death of Corporate Law 39 (European Corp. Governance Inst., Working Paper No. 402/2018, 2018), http://www.ecgi.global/sites/default/files/working_papers/documents/finalgoshenhannes. pdf [https://perma.cc/KXH3-CX55].

75. Luca Enriques \& Alessandro Romano, Institutional Investor Voting Behavior: A Network Theory Perspective 14 (European Corp. Governance Inst., Working Paper No. 393/2018, 2018), https://ecgi.global/sites/default/files/working_papers/documents/final enriquesromano.pdf [https://perma.cc/K4KR-8GCH].

76. See BIOY ET AL., supra note 38, at 3 ("[F] acing mounting pressure from a variety of stakeholders, asset managers have little choice but to increase their level of engagement with the companies they invest in and better demonstrate their commitment to driving change for the better to a diverse group of stakeholders around the globe."); Fisch et al., supra note 3, at 31 ("[F]iduciary duties partially explain why mutual funds, including passive investors exercise voice. Fiduciary duties also direct funds to exercise that voice in a manner that is intended to increase the value of the fund and its portfolio companies.").

77. In the United States, voting by mutual and public pension funds was fueled by regulatory action taken to enhance the fiduciary obligations applicable to voting proxies. First, by two companion SEC releases of 2003 addressing voting disclosures for registered management investment companies and registered investment advisers exercising voting authority over fund portfolios. Rock, supra note 9, at 376-78 (first citing Proxy Voting by Investment Advisers, 68 Fed. Reg. 6586 (Feb. 7, 2003) (to be codified at 17 C.F.R. pt. 275); and then citing Disclosure of Proxy Voting Policies and Proxy Voting Records by Registered Management Investment Companies, 68 Fed. Reg. 6564 (Feb. 7, 2003) (to be codified at 17 C.F.R. pts. 239, 249, 270, 274)). Second, by Department of Labor interpretative guidelines concerning the legal standards imposed by $\S \S 402,403$, and 404 of Title I of the Employee Retirement Income Security Act (ERISA). See 29 C.F.R. § 2509.2016-01 (20178) (articulating a general principle that a fiduciary's obligation to manage plan assets prudently extends to proxy voting). Those rulings were largely misinterpreted as requiring 
strategy that prompted - albeit without imposing a duty-institutional investors to extensively vote on all portfolio shares. ${ }^{78}$ In addition, it is

addressees to vote on all matters, that is to vote every proxy. See Rock, supra note 9, at 376-78; Lund, supra note 5, at 526-28. Further, SEC material explicitly recognized that votes based upon the recommendations of an independent third party can serve investment advisers to fulfill their fiduciary obligations under Rule 206(4)-6 and was further interpreted as requesting investment advisers to vote on all matters. See Douglas Scheidt, U.S. Sec. \& Exch. Comm'n, No-Action Letter to Kent S. Hughes, Egan-Jones Proxy Servs., on Proxy Voting by Investment Advisors, U.S. SEC. \& Exchange COMMISSION (May 27, 2004), https://www.sec.gov/divisions/investment/noaction/egan052704.htm [https://perma.cc/W94C-7VRC]; Douglas Scheidt, U.S. Sec. \& Exch. Comm'n, Letter to Mari-Anne Pisarri, Institutional S'holder Servs., on the Investment Advisors Act of 1940 - Rule 206(4)-6, U.S. SEC. \& ExChANGE COMmission (Sept. 15, 2004), https://www. sec.gov/divisions/investment/noaction/iss091504.htm [https://perma.cc/JAX9-56AF]. To tackle these unintended consequences, in 2014, the SEC Divisions of Corporate Finance and Investment Management released new guidance regarding the responsibilities of investment advisers concerning proxy voting. See Proxy Voting Responsibilities of Investment Advisers and Availability of Exemptions from the Proxy Rules for Proxy Advisory Firms: Staff Legal Bulletin No. 20 (IM/CF), U.S. SEC. \& EXCHANGE COMMISSION (June 30, 2014), http://www.sec.gov/interps/legal/cfslb20.htm\#_ftn1 [https://perma.cc/V2DH-C6VD]. Similarly, the Department of Labor revised its guidance in 2008 and 2016. See Interpretative Bulletin Relating to Exercise of Shareholder Rights, 73 Fed. Reg. 61,732 (Oct. 17, 2008) (to be codified at 29 C.F.R. pt. 2509) (clarifying that proxies should be voted as part of the process of managing the plan's investment in company stock unless a responsible plan fiduciary determined that the time and costs associated with voting proxies with respect to certain types of proposals or issuers may not be in the plan's best interest, and further stating that it is appropriate for a plan fiduciary to incur reasonable expenses in fulfilling those fiduciary obligations). Interpretive Bulletin 2008-2 was later withdrawn and replaced by Interpretive Bulletin 2016-1, which reinstates the language of Interpretive Bulletin 94-2 with certain modifications - illustrating that a discrete analysis of the cost of the shareholder activity versus the economic benefit associated with the outcome of the activity is not needed in any case but only under special circumstances, hence clarifying the conditions under which voting and engaging in areas, such as ESG, that are increasingly being internationally recognized as important to long-term shareholder value are compatible with a plan's fiduciary obligations not to sacrifice investment return or take on additional investment risk as a means of using plan investments to promote collateral social policy goals. Interpretative Bulletin Relating to the Exercise of Shareholder Rights and Written Statements of Investment Policy, 81 Fed. Reg. 95,879 (Dec. 29, 2016) (to be codified at 29 C.F.R. pt. 2509).

78. Similar to the United States, a duty to vote every share is not mandated under European law, although investment managers are still not allowed to remain passive and choose not to vote their shares because - depending on the investment strategies adopted - this might be in conflict with their duty to manage investments in the best interest of their clients. See, e.g., Christian Strenger \& Dirk A. Zetzsche, Corporate Governance, Cross-Border Voting and the (Draft) Principles of the European Securities Law Legislation Enhancing Investor Engagement Through Standardisation, 13 J. CORP. L. STUD. 503, 512 15 (2013) ("[A] conduct where institutional investors remain passive as a rule, and only 
credible that creating the appearance of governance expertise will help passive funds managers win over clients, especially among institutional investors. ${ }^{79}$

The conduct of the Big Three appears to confirm this last viewpoint. They frequently reiterate that they participate in the governance of investee companies. For example, in his letter to the CEOs of the world's largest companies in January 2018, Larry Fink, the CEO of Blackrock states that, in managing its index funds,

BlackRock cannot express its disapproval by selling the company's securities as long as that company remains in the relevant index. As a result, our responsibility to engage and vote is more important than ever. In this sense, index investors are the ultimate long-term investors - providing patient capital for companies to grow and prosper. 80

Furthermore, the Big Three have established stewardship teams, which are responsible for voting at investee companies' annual general meetings and for conducting engagement initiatives. ${ }^{81}$ Nevertheless, available data and empirical evidence on the impact of passive investing on corporate governance are mixed and do not definitively support either of the two opposing views mentioned above. ${ }^{82}$

engage exceptionally, imposes a liability risk on these investors. This is because these requirements, in addition to referencing systemic issues, rely on the presumption that shareholder voting preserves, or even increases, the long-term value of the investment. . . [T] his incentive structure in favour of voting [is] an implicit duty to vote."). It is also interesting to note that the Danish Stewardship Code has stated that a passive index-based investment does not automatically exempt the institutional shareholders from engaging in active ownership. COMM. ON CORP. GOVERnANCE, STEWARDShIP CODE 3 (2016), https:// corporategovernance.dk/sites/default/files/180116_stewardship_code.pdf [https://perma.cc/ 95MB-2S72].

79. Lund, supra note 5, at 527 ("[I]f the institution is perceived as being an involved and engaged steward, that will help funds attract assets and clients, especially from pension funds (a large and growing passive fund client) or other groups that view governance as a priority.")

80. See Larry Fink, Larry Fink's Annual Letter to CEOs: A Sense of Purpose, BLACKRoCK, https://www.blackrock.com/corporate/investor-relations/larry-fink-ceo-letter [https://perma.cc/LZ2A-XRQT]. For similar remarks from Vanguard's CEO, see McNabb, supra note 11.

81. See Rock, supra note 9, at 368-69; Fichtner et al., supra note 34, at 308.

82. Two factors make measuring the impact of passive investing difficult. First, "[c]orrelations between passive investors and governance choices might not reflect a causal relation since ownership by passive investors might be correlated with factorssuch as firms' investment opportunities or ownership by active investors- that directly affect managerial decisions." Appel et al., supra note 40, at 113. Second, the Big Three tend to prefer "behind the scenes" engagement, which has an impact that is, by nature, more difficult to identify. Joseph A. McCahery et al., Behind the Scenes: The Corporate Governance Preferences of Institutional Investors, 71 J. FIN. 2905, 2911, 2922-26 (2016); see also Fichtner et al., supra note 34, at 318. 
Although engagement and voting statistics provided periodically by the Big Three show that they vote extensively at the shareholder meeting of investee companies, ${ }^{83}$ the analysis of the Big Three's voting patterns raises doubts as to the capacity of the Big Three to perform an active stewardship role over investee companies and, indeed, their interest in doing so. In fact, statistics suggest that in most cases they vote in favor of the management proposal ${ }^{84}$ although the number of dissenting votes has been increasing slightly. ${ }^{85}$ Moreover, the data parallel the still limited empirical studies, which show passive investors often vote the same way and as a rule vote to approve the proposals made by the management. ${ }^{86}$ Consequently, there is widespread belief among corporate governance experts that to keep their fees low passive index funds should adhere to a low-cost box-ticking approach to voting. ${ }^{87}$

83. See, e.g., BlackRock, INVESTMENT STEWARDSHIP REPORT: 2017 Voting AND ENGAGEMENT REPORT 4-5 (2017), https://www.BlackRock.com/corporate/literature/ publication/blk-2017-annual-voting-and-engagment-statistics-report.pdf [http://perma.cc/ A63X-PDLH]; VANGUARD, INVESTMENT STEWARDShIP 2017 ANNUAL REPORT 28-33 (2017), https://about.vanguard.com/investment-stewardship/annual-report.pdf [http://perma.cc/ VH29-RMU6]. See generally State St. Glob. Advisors, 2017 Vote Summery RePort (2017), https://www.ssga.com/about-us/asset-stewardship.html [http://perma.cc/97D3EHZ5] (showing the voting statistics for all State Street Global Advisors accounts).

84. For example, all of the Big Three have backed the management in more than $90 \%$ of votes. Fichtner et al., supra note 34, at 317-18 (noting that the Big Three usually support management against activist shareholders' proposals and that more than half of the Big Three votes against management concern directors' re-elections); see also BLACKRoCK, supra note 83, at 4 ("Our starting position is generally to support management. . . . if we believe the issue under consideration is clearly not in our clients' economic interests [and] the company does not wish to engage with us or engagement fails to resolve our concerns."); BIOY ET AL., supra note 38, at 13 (noting that BlackRock and Vanguard tend to vote in favor of management more often than other firms).

85. See, e.g., VANGUARD, supra note 83, at 28-33. Interestingly, the percentage of voting against is higher in the EU than in the United States in relation to certain issuessuch as the adoption of anti-takeover measures like poison pills and thresholds for approval. See BIOY ET AL., supra note 38, at 13 ("[Asset managers in Europe tend to report higher . . percentages of 'Against' votes than their U.S. counterparts."); BLACKROCK, supra note 83, at 5 .

86. See Davidson Heath et al., Passive Investors are Passive Monitors 17-20 (Nov. 18, 2018) (unpublished manuscript), https://papers.ssrn.com/sol3/papers.cfm?abstract id $=3259433$ [https: $/ /$ perma.cc/R6F5-7FDU]. This finding is not uncontested. For example, some contend "greater ownership by passive funds is associated with less support for management proposal." Appel et al., supra note 40, at 127 . However, they do not provide evidence showing most passive index funds votes are against managers. See generally id.

87. See Lund, supra note 5, at 495 (noting passive investors tend to approve any shareholder proposal that meets pre-determined qualifications); see also Rana Foroohar, 
For sure, given the considerable number of portfolio companies, the stewardship teams at the Big Three are not capable of dedicating the same attention to all portfolio companies or preparing corporate governance reports for each. ${ }^{88}$ In fact, although they are expanding ${ }^{89}$ the investment stewardship teams at the Big Three are clearly too small. For example, Blackrock's team is made up of around thirty people who have the task of monitoring corporate governance issues of around 17,000 companies and of voting in around 17,000 shareholder meetings each year. ${ }^{90}$ So, as has been noted by Edward Rock, Big Three stewardship teams "[s]imply voting the shares, without even considering how to vote them, is an enormous task." 91 This means that Big Three stewardship teams draw up nearly identical voting guidelines, which they normally tend to follow fairly closely. ${ }^{92}$ For instance, in 2015 ,

Investors Pass the Buck on Governance, FIN. TIMES (Oct. 29, 2017), https://www. $\mathrm{ft.com} /$ content/f2510d5a-b961-11e7-8c12-5661783e5589; Attracta Mooney \& Robin Wigglesworth, Passive Fund Managers Face Showdown in US Gun Debate, FIN. TIMES (Mar. 2, 2018), https://www.ft.com/content/517fbbb6-1d4c-11e8-956a-43db76e69936.

88. See Lund, supra note 5, at 516. But see Fisch et al., supra note 3, at 27 ("[G]iven the fact that passive funds do not focus on individual firm-specific characteristics, the size of their governance staffs offers substantial manpower to analyze governance issues. By way of comparison, the total number of employees at many hedge funds, which engage in significantly greater firm-specific research, is not dramatically higher than full-time governance staff at the major passive investors." (citing Madison Marriage, BlackRock, Vanguard, and State Street Bulk Up Governance Staff, Fin. Times (Jan. 28, 2017), https://www.ft.com/content/657b243c-e492-11e6-9645-c9357a75844a)).

89. BIOY ET AL., supra note 38, at 19. For instance, in 2018 Vanguard created a new European stewardship team that is expected to include at least five members. Chris Flood, Vanguard Creates New European Stewardship Team, Fin. TimES (Feb. 17, 2018), https://www.ft.com/content/5dbd7d56-1256-11e8-940e-08320fc2a277.

90. BlackRock, InVestment Stewardship: Protecting OUR Clients' Assets FOR THE LONG-TERM 5, 13, 17 (2018), https://www.blackrock.com/corporate/literature/ publication/blk-profile-of-blackrock-investment-stewardship-team-work.pdf [http://perma.cc/ NQM8-673L]. For an in-depth analysis of how the stewardship teams of the Big Three function see Rock, supra note 9, at 368-71; see also Mooney \& Wigglesworth, supra note 87 (showing the Big Three's stewardship teams in numbers); Lund, supra note 5, at 51516 (noting that the Big Three's stewardship teams are devoted to governance issues at thousands of companies).

91. Rock, supra note 9, at 370 (emphasis omitted); see also Bebchuk et al., supra note 3, at 100 ("[E]ach of these major investment managers devotes less than one personworkday per year, on average, to assessing this and other information, and undertaking other stewardship activities with respect to each of their portfolio companies."); Asaf Eckstein, Great Expectations: The Peril of an Expectations Gap in Proxy Advisory Firm Regulation, 40 DEL. J. CORP. L. 77, 93 n.118 (2015) ("Michelle Edkins, Managing Director and Global Head of Investment Stewardship at BlackRock, Inc., remarked, 'We are all under time pressure, huge time pressure. There are days when we are voting 25,30 meetings across our team." (citation omitted)).

92. See, e.g., Vanguard's Proxy Voting Guidelines, VANGUARD, https://about.vanguard.com/ investment-stewardship/policies-and-guidelines/\# [https://perma.cc/2D42-LCYP] ("[T]he 
[a]t BlackRock, in 18 per 100,000 of the proposals one of their funds did not vote along with the other funds, and for Vanguard this is even more consistent with only 6 per 100,000 of the proposals receiving mixed votes. State Street also show[ed] a low level of internal disagreement, 195 per 100,000, though somewhat higher than BlackRock and Vanguard. ${ }^{93}$

In addition, these voting patterns may be a consequence of the fact that the Big Three rely largely on proxy advisory firms' services - mainly those of Institutional Shareholder Services (ISS) and Glass Lewis ${ }^{94}$ — which, in turn, adopt standardized voting policies. ${ }^{95}$

Nevertheless, perhaps because of the growing reputational and regulatory pressure for asset managers to provide strong corporate oversight, ${ }^{96}$ some passive fund managers insistently state that they adopt a more nuanced approach to voting and do not automatically adhere to proxy advisors' recommendations. ${ }^{97}$ In particular, BlackRock states that although it votes

guidelines adopted by the Board provide a rigorous framework for assessing each proposal. Under the guidelines, each proposal must be evaluated on its merits, based on the particular facts and circumstances as presented."); see also StATE ST. GLOB. AdvisOrS, ANNUAL STEWARDSHIP REPORT 2017 YEAR END 12 (2018), https://www.ssga.com/investmenttopics/environmental-social-governance/2018/07/annual-stewardship-report-2017.pdf [https://perma.cc/DT23-ZSP8] (declaring that State Street adheres strictly to adopted voting policy and all its voting and engagement activities are centralized within the asset stewardship team irrespective of investment strategy or geographic region).

93. Fichtner et al., supra note 34, at 317 (noting that, by contrast, Fidelity - the world's largest actively managed fund group - shows "internal disagreement in 3,144 per 100,000 votes"); see also Lund, supra note 5, at 517 ("Th[e] higher degree of inconsistency [shown by active fund managers] is likely due to the fact that institutions with a greater share of active investments, like Fidelity, tend to give active fund managers freedom to cast the fund's votes, and different fund managers will reasonably reach different conclusions for controversial proposals or have varying perspectives based on the differing needs of their investors. And it indicates that the centralized voting strategy utilized by passive funds may not be in the best interests of all investors." (footnotes omitted)).

94. BIOY ET AL., supra note 38, at 14.

95. See Gaia Balp, Regulating Proxy Advisors Through Transparency: Pros and Cons of the EU Approach, 14 EuR. COMPANY \& FIN. L. REV. 1, 9 (2017).

96. See supra note 77-78 and accompanying text; see also BIOY ET AL., supra note 38 , at 3 .

97. See Enriques \& Romano, supra note 75, at 15 ("[I]t would be politically unacceptable for [the largest institutional investors] to have their humongous voting power de facto exercised by an external advisor with no direct or indirect stake in the company."). As regards Vanguard, evidence consistent with this prediction are provided by Stephen Choi and his colleagues. See Stephen Choi et al., Who Calls the Shots?: How Mutual Funds Vote on Director Elections, 3 HARV. BuS. L. REV. 35, 56-59 (2013); see also Ed Batts, BlackRock Talks . . and U.S. Companies Must Listen, HARV. L. SCH. F. ON CORP. 
on routine matters based on voting policy guidelines, ${ }^{98}$ a detailed in-house review is carried out whenever specific problems arise. ${ }^{99}$ Moreover, BlackRock notes that it does "not follow any single proxy advisor's voting recommendations, and in most markets ... subscribes to two research providers." $" 100$ Proxy advisors are just one of many tools that BlackRock uses to make its voting decisions. ${ }^{101}$ Therefore, based on this flexible approach, index and active funds managed by BlackRock can cast votes differently where they may have a different perspective concerning any given issue. ${ }^{102}$ Consequently, even though the available data show they "follow a "check the box' approach" in most cases — which does not consider the specific needs of each portfolio company ${ }^{103}$ - an analysis of their voting patterns does not suffice to conclude that the Big Three are also passive owners. ${ }^{104}$

In fact, rather than by voting against, they prefer to influence managers through private engagement with them. ${ }^{105}$ Such a "hidden power" 106 of leading passive fund managers seems to be consistent with further analysis showing that, where a passive index fund holds a large ownership stake, this hidden power is associated with some significant corporate governance improvements. ${ }^{107}$ In particular, Ian Appel, Todd Gormley, and Donald Keim, found passive index fund influence supported greater board independence, favored the removal of takeover defenses - restrictions on the shareholders' ability to call a special meeting or classified board - and promoted more equal voting rights by opposing dual class share structures. ${ }^{108}$

However, the data collected by other scholars points to a slightly more nuanced view. Nan Qin and Di Wang note that the growth in passive ownership may lower the quality of governance within investee companies by reducing the independence of the board of directors and increasing the

GOVERNANCE \& Fin. REG. (Feb. 13, 2018), https://corpgov.law.harvard.edu/2018/02/13/ blackrock-talks-and-u-s-companies-must-listen [https://perma.cc/QS6E-5WFY].

98. BIOY ET AL., supra note 38, at 26 (reporting that BlackRock directs routine votes to ISS, which votes in line with the instructions outlined in BlackRock's policy).

99. BLACKROCK, supra note 83, 13-14.

100. Id. at 15 (emphasis omitted).

101. See id. at $13-15$.

102. Id. at 13.

103. Appel et al., supra note 40, at 134

104. See Fichtner et al., supra note 34, at 306-07.

105. See supra note 83; see also Fisch et al., supra note 3, at 25-27.

106. Fichtner et al., supra note 34, at 298, 323.

107. See Appel et al., supra note 40, at 127-28 (contending large passive investors "use their ownership stake and ability to vote to" influence companies' corporate governance).

108. Id. at 123-34 (pointing out that their findings do not address the further question whether passive investors look at the governance needs of each single company or, instead, follow pre-defined voting policy). 
likelihood of CEO-chair duality. ${ }^{109}$ Along the same lines, Cornelius Schmidt and Rüdiger Fahlenbrach show that, in companies where passive index funds have large shareholdings, the power of CEOs increases - demonstrated by the fact that they more frequently become chairman or president - and independent director turnover decreases, with such directors serving longer terms. ${ }^{110}$ In addition, and perhaps more interestingly, Schmidt and Fahlenbrach find that a greater proportion of passive investors in the shareholder base is associated with more value-destroying mergers and acquisitions (M\&A) activities. ${ }^{111}$ Therefore, this outcome seems to be consistent with the hypothesis that passive investors are less likely to monitor managers. ${ }^{112}$

As Schmidt and Fahlenbrach note, this evidence does not necessarily imply passive investors are also entirely passive owners and is also not inconsistent with the apparently diverging findings mentioned above. ${ }^{113}$ In fact, the overall body of available data and evidence seems to suggest passive index funds can have a positive impact on corporate governance issues for which low-cost interventions are required, such as voting according to pre-defined policies at annual meetings. ${ }^{114}$ By contrast, passive investors are deemed to be generally passive owners "when it comes to high-cost governance activities such as monitoring of M\&A, the choice of board members, or the accumulation of titles that often happen outside of annual general meetings and require continuous monitoring." 115 Moreover, this

109. Qin \& Wang, supra note 67, at 25-26 ("'[H]igher ownership by passive investors is related to lower firm value measured by Tobin's Q and weaker operating performance measured by return on assets. ... [P] assive investors exacerbate the managerial myopia problem by discouraging corporate long-term investment measured by R\&D and capital expenditure.").

110. Cornelius Schmidt \& Rüdiger Fahlenbrach, Do Exogenous Changes in Passive Institutional Ownership Affect Corporate Governance and Firm Value?, 124 J. FIN. ECON. 285, 293-94 (2017).

111. Id. at $298-300$

112. Id. at 299-300. But see Ahmed Baig et al., Passive Ownership and Earnings Manipulation 6 (Feb. 28, 2018) (unpublished manuscript) (on file with author) ("'D]emonstrating that passive ownership affects firms in a positive way by reducing their susceptibility to committing financial statement fraud.").

113. Schmidt \& Fahlenbrach, supra note 110, at 287, 300.

114. This is in line with the view that "the Big Three enjoy substantial economies of scale with respect to corporate governance and market-wide initiatives." Fisch et al., supra note 3, at 13, 17 ("Passive investors own the entire market and therefore also enjoy economies of scale in evaluating governance provisions, because the same governance provisions are likely to be in play at multiple companies within the passive fund's portfolio.").

115. Schmidt \& Fahlenbrach, supra note 110, at 287 (emphasis omitted); see also Fisch et al., supra note 3, at 15 ("Because of the large size of their portfolios and their 
view is backed by anecdotal evidence that shows the Big Three mainly focus on topics - corporate governance, board composition, climate risk disclosure - that require low-cost interventions, normally by voting at the shareholders' meeting. ${ }^{116}$

Although the available evidence is still limited and insufficient to draw a final conclusion, the engagement practices of the Big Three seem to be generally consistent with this view. In keeping with their frequent assertions that their engagement is an essential element of their investment stewardship programs,${ }^{117}$ the Big Three engage with hundreds of investee companies. For instance, in 2016, BlackRock disclosed 1,480 engagements, Vanguard 817 , and State Street $611 .^{118}$ The number of engagements by the Big Three is high considering other significant, albeit smaller, passive fund managers reported a limited number of engagements. For example, Deutsche Asset Management, which has $15 \%$ of its asset under management invested in passive funds, reported only thirty-seven engagements in $2016 .{ }^{119}$

However, these numbers do not tell the whole story. First, although the figure is high in absolute terms, the number of engagements reported by the Big Three is limited when compared to the number of their portfolio companies. For example, if BlackRock invests in around 17,000 companies, no engagement activity is carried out for around 14,800 of these. ${ }^{120}$ Second, although meetings between investee companies and institutional investors that invest mainly in active funds are conducted mainly by investment analysts - for whom corporate governance engagement is merely

limited firm-specific knowledge, passive investors are poorly-positioned to identify the firm-specific operational qualities that would enable them to prompt individual companies to outperform.").

116. For example, BlackRock's engagement priorities for 2017-2018 include governance, corporate strategy, compensations, climate risk disclosure, and human capital. Abe M. Friedman \& Robert McCormick, BlackRock's 2017-2018 Engagement Priorities, Harv. L. Sch. F. ON CorP. Governance \& Fin. Reg. (Mar. 17, 2017), https://corpgov.law.harvard.edu/2017/03/17/BlackRocks-2017-2018-engagement-priorities/ [https://perma.cc/5AP9-S5T9]. Similarly, Vanguard indicates four stewardship pillars: board, corporate governance structure, compensation, and risk. VANGUARD, supra note 83, at 5; see also Eckstein, supra note 64, at 30-33; Fisch et al., supra note 3, at 19.

117. See, e.g., BlackRock, Investment Stewardship: Global Corporate GOVERNANCE \& ENGAGEMENT PRINCIPLES 3 (2017), https://www.BlackRock.com/corporate/ literature/fact-sheet/blk-responsible-investment-1 engprinciples-global-122011.pdf [https:// perma.cc/P7VN-ZBP6] ("BlackRock views engagement as an important activity; engagement provides BlackRock with the opportunity to improve our understanding of investee companies and their governance structures, so that our voting decisions may be better informed."); Chris Wightman, Engaging with Vanguard, HARV. L. SCH. F. ON CORP. Governance \& FIN. REG. (Mar. 8, 2018), https://corpgov.law.harvard.edu/2018/03/08/engaging-withvanguard/ [https://perma.cc/BP39-J8G7].

118. BIOY ET AL., supra note 38, at 16.

119. Id.

120. See Lund, supra note 5, at 519. 
a complementary aspect of their work - in firms where passive funds predominate engagement initiatives are conducted by investment stewardship teams that cannot always count on the cooperation of and exchange of information with investment teams and portfolio managers. ${ }^{121}$

For example, at Vanguard, active funds use external advisors to manage investments. ${ }^{122}$ Therefore, although the stewardship team at Vanguard uses input from its subadvisors for its voting and engagement activities, it does not seem to be able to leverage their expertise as effectively as stewardship teams at other firms that have in-house research and investment teams. ${ }^{123}$ Moreover, although passive funds may free ride on information from active funds when the same institution - for example, BlackRock, has its assets invested in both active and passive funds ${ }^{124}$ - this free-riding opportunity is likely limited as active funds invest in far fewer companies than passively managed funds. In addition, because of the continuous outflow of resources from actively managed funds, investment institutions are likely to reduce the workforce dedicated to investment analysis. ${ }^{125}$

Third, also because of the observation made above, Big Three stewardship teams rarely engage with companies concerning business related strategies, as this would give rise to significant costs, thereby increasing the fee charged by passive index funds. ${ }^{126}$ This would appear confirmed by the indications provided in the stewardship policies and reports of the Big Three, which demonstrate that their engagement efforts are mainly concentrated on environmental, social, and governance (ESG) matters; with regard to business-related issues - such as M\&A - they tend to vote according to their voting policies and in the vast majority of cases in favor of the management. ${ }^{127}$ More notably, at BlackRock, from July 1, 2016 to June

121. See BIOY ET AL., supra note 38, at 16 ("[I]n firms where active management dominates ... the portfolio managers and ESG analysts primarily drive the engagement process."); see also Fisch et al., supra note 3, at 22.

122. See BIOY ET AL., supra note 38, at 46.

123. See id. at 16.

124. See State St. Glob. Advisors, supra note 92, at 10 ("[State Street]'s corporate stewardship team works closely with [its] active fundamental investment teams, collaborating on issuer engagements and sharing input on company-specific fundamentals."); see also Fisch et al., supra note 3, at 18.

125. See Fisch et al., supra note 3, at 3 .

126. See Schmidt \& Fahlenbrach, supra note 110, at 300; see also Eckstein, supra note 64 , at 30 ("Incentives of institutional investors to monitor their portfolio companies depend on the relative costs and benefits of monitoring."); Partnoy, supra note 5.

127. See BlACKRock, supra note 83, at 3; STATE ST. GlOB. AdVISORS, supra note 92, at 27 (reporting that, in 2016, only $3 \%$ of engagements related to merger and acquisitions); 
30, 2017, most engagements were qualified as "basic" and generally amounted to one single conversation concerning a routine matter. ${ }^{128}$ By contrast, only 147 of 1,274 engagements qualified as "extensive" engagementstechnically complex, high-profile, and involving numerous meetings over a longer timeframe. ${ }^{129}$

\section{B. Indirect Corporate Governance Consequences of Passive Investing: The Impact on Activism}

According to Gilson and Gordon's definition, institutional investors are "rationally reticent," as they are willing to respond to governance proposals but are unwilling to advance them and use their voting power unless they are stimulated by activist shareholders. ${ }^{130}$ The rise of passive investing is destined to increase the tendency of institutional investors to be rationally reticent. The continuous flow of invested assets from actively managed funds to passive index funds may induce active fund managers to adopt a low cost investment strategy - to reduce the costs associated with engagement with investee companies - thereby containing fees and avoiding outflow of clients. ${ }^{131}$ This evolution confirms institutional investors have a limited incentive to play an active governance role, and hedge funds should act as "catalysts" in facilitating shareholder action. ${ }^{132}$

By contrast, because of their performance-related fee structure, activist hedge fund managers have stronger incentives to invest in stewardship: they are able to capture a significant share of the value increase generated by governance-related campaigns. ${ }^{133}$ In addition, "for activist hedge funds, activism is ex ante and strategic." 134 In fact, "[a]ctivists first identify a problematic company, then decide whether intervention can improve matters. If activists conclude that an intervention is warranted, they buy

VANGUARD, supra note 83, at 28-33 (reporting that, in 2017, it sided with the management in almost all the proposals concerning merger and acquisitions - $100 \%$ in the United States and $97 \%$ in the EU).

128. BLACKROCK, supra note 83 , at 3.

129. Id.

130. Gilson \& Gordon, supra note 8, at 888-902.

131. See K.J. Martijn Cremers \& Quinn Curtis, Do Mutual Fund Investors Get What They Pay For? Securities Law and Closet Index Funds, 11 VA. L. \& Bus. REV. 31, 31, 4546 (2016) ("A purportedly active fund with a portfolio that substantially overlaps with the market or any indexed market segment is known as a closet index fund.").

132. Rock, supra note 9, at 382; see also Bebchuk et al., supra note 3, at 104-07; Gilson \& Gordon, supra note 8, at 896-97. See generally Marcel Kahan \& Edward B. Rock, Hedge Funds in Corporate Governance and Corporate Control, 155 U. PA. L. REV. 1021 (2007); Edward B. Rock, The Logic and (Uncertain) Significance of Institutional Shareholder Activism, 79 GEO. L.J. 445 (1991).

133. Bebchuk et al., supra note 3, at 104-06.

134. Rock, supra note 9, at 382 (citing Kahan \& Rock, supra note 132, at 1069). 
a stake in order to intervene." ${ }^{\prime 135}$ However, because hedge funds usually hold a minority stake, which is not sufficient to prevail within investee company shareholder meetings, they must seek the support of nonactivist institutional investors in order to impose their strategy. ${ }^{136}$ Because the Big Three, taken together, hold large shareholdings in many listed companies and their votes are often decisive within contested director elections and management proposals, ${ }^{137}$ interaction between activist hedge funds and passive investors takes on a major importance. ${ }^{138}$

Nevertheless, it is questionable whether passive fund managers have any interest in supporting campaigns by activist hedge funds. As has recently been outlined by Dorothy Lund, various arguments appear to suggest passive index funds are unlikely to support activists' initiatives. ${ }^{139}$ First, because the potential beneficial effects of activist intervention will not improve the passive fund's relative performance, they are unlikely to bear the costs of evaluating — and possibly supporting — an activist campaign. ${ }^{140}$ Moreover, passive fund managers might refrain from supporting an activist to avoid "jeopardiz[ing their] relationship with the target company and put[ting] the fund at risk of losing corporate pension fund assets." 141 In addition, based on the growing body of scholarship that claims that Big Three horizontal investing across competing firms has anticompetitive effects, passive fund managers have no incentive to back activist campaigns because their success

135. Id.

136. Id.; see also Alessio M. Pacces, Exit, Voice and Loyalty from the Perspective of Hedge Funds Activism in Corporate Governance, 4 ERASMus L. REV. 199, 208 (2016); Fisch et al., supra note 3, at 18.

137. See supra Part II.

138. See Simi Kedia et al., Institutional Investors and Hedge Fund Activism 31 (Nov. 2016) (unpublished manuscript) (on file with authors), https://editorialexpress.com/cgibin/conference/download.cgi?db_name=AFA2018\&paper_id=342 [https://perma.cc/4Q7Z7ET8]; Alessio M. Pacces, Hedge Fund Activism and the Revision of the Shareholder Rights Directive 14-16 (European Corp. Governance Inst., Working Paper No. 353/2017, 2017), https://ecgi.global/sites/default/files/working_papers/documents/3532017.pdf [https:// perma.cc/3PT6-9K36].

139. Lund, supra note 5, at 520-21.

140. Id. at 520 ("First, because passive funds lack information about the company and its performance, they would need to invest time and resources to evaluate the activist's proposal. Second, supporting an activist would cause the fund to incur the costs of interfacing with management and potentially participating in litigation." (citing Robert C. Pozen, The Role of Institutional Investors in Curbing Corporate Short-Termism, 71 FIN. ANALYSTS J. 81, 83 (2015)).

141. Id. 
could lead to the adoption of more aggressive strategies that could harm other companies included in the passive funds' portfolios. ${ }^{142}$

This prediction proves to be consistent with the limited empirical analysis concerning voting by passive funds within proxy contests. Alon Brav, Wei Jiang, and Tao Lishow "passively-managed funds are significantly less likely than active funds to vote for dissidents" and, more generally, that "the most pro-dissident fund families typically have a low [proportion] of passive funds." 143 Specifically, "the number of passive funds within the family" is correlated both with their participation in a proxy contest and with their "support for management." 144 Therefore, Big Three passive funds are likely to influence voting by active funds managed by the same institution. In addition, Brav and his colleagues found that the level of passive fund investment in the firm targeted by activists correlates negatively with support for the dissident. ${ }^{145}$ This is consistent with the hypothesis "that passive funds with significant investment in target firms, often belonging to large families that also manage the targets' retirement assets, are less likely to challenge the management because of potential conflicts."146

Nonetheless, especially over the last few years, the interplay between passive index funds and activist hedge funds has been undergoing significant changes. ${ }^{147}$ Although in most cases passive investors continue to side with management, the Big Three have been displaying signs of greater openness towards activist investors. First, within proxy contests, the Big Three support activists in a significant number of cases. ${ }^{148}$ Notably, BlackRock "voted

142. Id. at 521

143. Alon Brav et al., Picking Friends Before Picking (Proxy) Fights: How Mutual Fund Voting Shapes Proxy Contests 3 (Columbia Bus. Sch., Working Paper No. 18-16, 2018).

144. Id. at 19 ("[T]he most pro-dissident families tend to have few passively managed funds, and vice versa.").

145. Id. at app. at 8. Brav and his colleague's conclusions are consistent with Appel and his colleague's analysis excluding the existence of a positive correlation between ownership by passive funds and the likelihood of a firm experiencing hedge fund activism event or a takeover; indeed, the holding of a larger ownership stake by passive funds has been found to be associated with a decline in hedge fund activism. Appel et al., supra note 40 , at 128 .

146. Brav et. al, supra note 143, at app. at 8; see also Bebchuk et al., supra note 3, at 103; Fisch et al., supra note 3, at 34.

147. See Fisch et al., supra note 3, at 24 ("Passive investors both benefit from activists and mediate their influence.").

148. See Brav et al., supra note 143, at 19, 49 ("The support rate for dissidents ranges from $16.8 \%$ by Vanguard to $34.8 \%$ by BlackRock."); see also LAZARD, 2017 ACTIVISM YEAR IN REVIEW 1 (2018), https://www.lazard.com/media/450414/lazards-review-ofshareholder-activism-q4-2017pdf.pdf [https://perma.cc/QA39-27HH]; Sahil Mahtani, Telecom Italia Vote Shows How Activists and Passive Investors Can Work Together, CLS BLUE SKY BLOG (May 16, 2018), http://clsbluesky.law.columbia.edu/2018/05/16/telecomitalia-vote-shows-how-activists-and-passive-investors-can-work-together/ [https://perma.cc/ CWW2-P2AH]. 
in favor of the activist Nelson Peltz . . . in his proxy fight with Procter \& Gamble [and also] in favor of Bill Ackman against ADP." "149 At Exxon's May 31, 2017 annual general meeting, the support of BlackRock and Vanguard proved decisive in approving the shareholder proposal seeking the enhanced disclosure of climate-related risks. ${ }^{150}$

Therefore, the interplay between passive fund managers and activist investors is becoming increasingly important. On the one hand, passive investors are paying increasing attention to activists' campaigns. For example, Vanguard reported that "[p]roxy contests and contentious transactions were a prominent issue in [2016] and were discussed at 16\% of [its] engagements." ${ }^{151}$ Along the same lines, BlackRock defines its engagement approach as follows: it engages with the activist investor if it believes doing so would provide a better understanding of their proposals, and when activists are seeking board seats it "usually meet[s] with the nominees in advance of the shareholder meeting to understand what they believe they would bring to the board." 152

On the other hand, although "a relatively pro-activist shareholder base is a key factor driving activists' selection of targets" 153 and, therefore, it is likely that they will prefer to target companies where the presence of passive investors is less marked, activists are increasingly willing to seek the support of passive investors, which frequently turns out to be the key for the success of the activist campaigns. ${ }^{154}$ Consequently, activist investors appear to be ever more inclined to "tailor their interventions to satisfy" passive investors, ${ }^{155}$ as shown by their increasing tendency "to appeal to the

149. Andrew Ross Sorkin, BlackRock's Message: Contribute to Society, or Risk Losing Our Support, N.Y. TIMES (Jan. 15, 2018), https://nyti.ms/2FHQonI.

150. Steven Mufson, Financial Firms Lead Shareholder Rebellion Against ExxonMobil Climate Change Policies, WASH. POST (May 31, 2017), https://www.washingtonpost.com/ news/energy-environment/wp/2017/05/31/exxonmobil-is-trying-to-fend-off-a-shareholderrebellion-over-climate-change/?utm_term=.dbcc54736ca4 [https://perma.cc/KZU6-VA2H].

151. VANGUARD, supra note 83, at 24.

152. BLACKROCK, supra note 83, at 14; see also Wightman, supra note 117 (explaning that Vanguard adopts an identical approach).

153. See Brav et al., supra note 143, at 1.

154. See Ethan A. Klingsberg \& Elizabeth Bieber, Activism in 2018, HARV. L. ScH. F. ON CORP. GOVERNANCE \& FIN. REG. (Jan. 29, 2018), https://corpgov.law.harvard.edu/ 2018/01/29/activism-in-2018 [http://perma.cc/GPX2-9GSR]

155. Lund, supra note 5, at 522; see also Fisch et al., supra note 3, at 24-25 ("Passive funds have a potentially critical role in screening activism because their incentives may differ from those of the activists. Passive investors share in company-wide gains from valuable activism, but they lose if the activist can implement changes that produce short 
longer-term and often structural and governance-oriented concerns of the passive strategy fund shareholders." 156

The impact of passive investing upon activist investors' strategic choices and goals has been investigated in a recent study by Appel and his colleagues, which was the first to address the issue. ${ }^{157}$ This study shows the rise of passive investors - associated with more frequent activist campaigns entailing confrontational and costlier tactics, which are often aimed at gaining board seats - and a corresponding decrease in other types of campaigns including those seeking to improve shareholder value by demanding policy changes such as increased dividends. ${ }^{158}$ In addition, higher passive ownership is correlated with a higher number of proxy fights and a sizeable increase in the likelihood of a proxy settlement with management, which often results in the activist obtaining board representation. ${ }^{159}$

These findings still appear too limited to draw definitive conclusions and can be interpreted in different and somewhat contrasting ways. On the one hand, frequent use of aggressive tactics by activists may negatively impact corporate value by shortening the company's investment horizon. ${ }^{160}$ However, some anecdotal evidence show the rise of passive investing could refocus activists to adopt strategies that are more oriented to the long-term and that more broadly consider a company's social responsibility-related issues. ${ }^{161}$ Thus, although the findings mentioned above could be a consequence

term gains but destroy the company for the long term, because passive investors, unlike active investors, cannot exit before that happens. These incentives are likely to make passive investors take a more cautious approach and be less willing than actively-managed funds to support some activists." (footnote omitted)); McNabb, supra note 11 ("The nature of activist investing has changed significantly since the 1980s. Today, we're seeing a greater trend toward constructive activists rather than destructive activists. Activists are not inherently good or bad. They often raise legitimate questions. When activists raise legitimate questions and tie their business cases to long-term shareholder value, that gets our attention.").

156. Klingsberg \& Bieber, supra note 154; see also LAZARD, REVIEW OF SHAREHOLDER ACTIVISM -1Q 2018, at 1 (2018), https://www.lazard.com/media/450655/lazards-reviewof-shareholder-activism-1h-2018.pdf [https://perma.cc/EGV7-632H].

157. See generally Appel et al., Standing on the Shoulders of Giants: The Effect of Passive Investors on Activism (Nat'l Bureau of Econ. Research, Working Paper No. 22707, 2016), https://www.nber.org/papers/w22707.pdf [https://perma.cc/G9YM-5X42].

158. Id. at 18-25; see also LAZARD, supra note 156, at 9-10.

159. Appel et al., supra note 157, at 18-22.

160. For the diffused criticism concerning the activists' short-term perspective, see generally John C. Coffee, Jr. \& Darius Palia, The Wolf at the Door: The Impact of Hedge Fund Activism on Corporate Governance, 41 J. CoRP. L. 545 (2016); Leo E. Strine, Jr., Can We Do Better by Ordinary Investors? A Pragmatic Reaction to the Dueling Ideological Mythologists of Corporate Law, 114 CoLuM. L. REV. 449 (2014).

161. For example, in 2017 the well-known activist hedge fund, JANA Partnersusually focused on improvement through mergers and acquisitions or operational improvements at target companies - allied with public pension fund California State Teachers' Retirement 
of the fact that it is less expensive to organize a campaign within companies where ownership is more concentrated, ${ }^{162}$ available evidence underscores the hypothesis that activists tend to prefer tactics aimed at pursuing longterm and governance-related objectives in line with the preference of passive investors. ${ }^{163}$ Therefore, contrary to what might have been predicted at first glance, passive investing could limit widespread concerns on shorttermism on the part of activist hedge funds. ${ }^{164}$

\section{RECONSIDERING THE APPROACH TO INSTITUTIONAL INVESTOR ENGAGEMENT IN THE ERA OF PASSIVE INVESTING: THE KEY PROBLEM IS ONE OF COSTS, NOT SHORT-TERMISM}

Passive index funds are necessary long-term investors because they cannot see the shares included in the index they are tracking. ${ }^{165}$ Thus, they vote extensively at the shareholder meetings of investee companies

System to urge Apple to take actions aimed at curbing growing addiction among children to Apple's devices. Robert G. Eccles, Why an Activist Hedge Fund Cares Whether Apple's Devices Are Bad for Kids, HARV. BuS. REv. (Jan. 16, 2018), https://hbr.org/2018/01/whyan-activist-hedge-fund-cares-whether-apples-devices-are-bad-for-kids [https://perma.cc/ FFD2-BTP5] ("[A]ctivists are actually no strangers to seeking returns from genuine, longterm value creation."); see also Virginia Harper Ho, Risk-Related Activism: The Business Case for Monitoring Nonfinancial Risk, 41 J. CORP. L. 647, 696-701 (2016); Lindsay Fortado, Investing: Activism Enters the Mainstream, FIN. TIMES (Feb. 13, 2018), https:// www.ft.com/content/e04547b8-0d0b-11e8-839d-41ca06376bf2 ("[M]any [hedge funds] stress that they are holding positions for longer and not clamouring for share buybacks or quick sales, but rather urging changes they claim will help the company long-term."); Owen Walker, Hedge Funds Boost 'Responsible Investment' Strategies, FIN. TIMES (May 26, 2018), https://www.ft.com/content/5cb7bcd4-5f5c-11e8-9334-2218e7146b04 (reporting that activists are ever more inclined to integrate ESG factors into their campaigns).

162. See Appel et al., supra note 157, at 20-21.

163. See id. at 29; see also Christopher P. Skroupa, Passive Investors and Their Role in Activism For 2018, ForBES (Dec. 20, 2017, 11:47 AM), https:/www.forbes.com/sites/ christopherskroupa/2017/12/20/passive-investors-and-their-role-in-activism-for-2018/3/ \#18f4bf066f12 [https://perma.cc/B8GV-AY73] ("As both activists and the companies they look at have sought greater influence amongst passive funds, a 'passive-centric' mindset has developed in the marketplace.").

164. See Appel et al., supra note 157, at 29 ( "[P] assive investors have been shown to be strong supporters of good governance practices that are consistent with long-term firm value ... and we provide evidence here that passive institutional ownership also bolsters the efforts of activists that seek see similar goals.").

165. See Fisch et al., supra note 3, at 4; Joshua Kennon, Investing in Index Funds for Beginners (Nov. 1, 2018), https://www.thebalance.com/investing-in-index-funds-for-beginners356318 [https://perma.cc/9AHR-YUB5]. 
and engage with a significant number of them-albeit on a limited scale in proportion with the overall number of portfolio companies. ${ }^{166}$ Moreover, passive index funds, including the Big Three, pay close attention to ESG issues with the aim of driving and sustaining the long-term growth of investee companies in the interest of their clients. ${ }^{167}$ Indeed, the rise of passive investing has been associated with a rise in responsible investing, as is shown, for example, by the ever increasing number of signatories to the Principles for Responsible Investment (PRI). ${ }^{168}$ Leading passive index fund managers repeatedly reassert their commitment to stimulating investee companies to take responsibility for their impact on society to "benefit all of their stakeholders, including shareholders, employees, customers, and the communities in which they operate." 169

Thus, the rise of passive investing seems to represent an evolution in the investment industry, which is perfectly in line with the objectives of the EU Commission's corporate governance strategy because passive investors - perhaps, surprisingly — feature characteristics of active owners that are considered "the "right' kind of ownership" at the EU level. ${ }^{170}$ In fact, in the 2011 Green Paper, the EU Commission clearly stated that an active, long-term oriented shareholder should "actively monitor[] portfolio companies, engage[] in dialogue with the company's board, and [exercise] shareholder rights." 171 Along the same lines, the SHRD II also emphasizes the importance of effective and sustainable shareholder engagement and highlights that " $[\mathrm{g}]$ reater involvement of shareholders in corporate governance is one of the levers that can help improve the financial and nonfinancial performance of companies, including as regards environmental, social and governance factors." ${ }^{172}$ Consequently, some of the criticisms leveled against the disclosure-based initiatives set out by the SHRD II to promote engagement by institutional shareholders could be reconsidered from a different perspective in the light of the rise of passive investing.

In particular, the EU Commission's assumption that the increased disclosure of institutional investors' investment and engagement strategies could "facilitate the dialogue between companies and their shareholders,

166. See BIOY ET AL., supra note 38, at 3, 23.

167. See, e.g., Fink, supra note 80.

168. See BIOY ET AL., supra note 38 , at $9-10$.

169. Fink, supra note 80.

170. Madsen, supra note 28, at 145-50; see also Fisch et al., supra note 3, at 38 (" $[\mathrm{F}]$ or those concerned with the short-termism that may accompany greater monitoring by active mutual funds and hedge funds, passive investors with a significant ownership stake serve as a valuable antidote.").

171. Green Paper: The EU Corporate Governance Framework, at 11, COM (2011) 164 final (Apr. 5, 2011) [hereinafter EC Green Paper].

172. SHRD II, supra note 17 , at 3. 
encourage shareholder engagement and strengthen their accountability to stakeholders and to civil society" is criticized. ${ }^{173}$ Critics of the EU Commission's approach assert, in the first place, that increased transparency yields limited effects because it does not create financial incentives or lower the costs of engagement. ${ }^{174}$ Second, the disclosure of engagement policies and activities could negatively impact institutional investors" "willingness to engage in this type of activism" 175 because they may prefer "behind the scenes engagement." "176 In addition, because according the SHRD II, Article 3c, disclosure of an engagement policy is optional on a "comply or explainbasis," 177 such a disclosure-based strategy is considered too flexible to induce institutional investors to engage actively with investee companies.

However, within a context where leading passive index fund managers focus on long-term value creation and ESG issues - for example in annual letters from their $\mathrm{CEOs}^{178}$ - the disclosure of the engagement policy could place further pressure on other institutional investors and push them to engage more actively with the investee company. ${ }^{179}$ As noted above, the available evidence shows the capacity of passive investors to influence activist hedge funds' strategies by re-orienting them towards a longer term strategy. ${ }^{180}$ What is more, the continuous advance of passive investors who heavily focus on ESG issues could induce the managers of actively managed mutual funds to commit to responsible investing and to incorporating ESG issues into the investment process. The fact that paying greater attention to ESG issues is capable of attracting a certain type of clientpension funds - attributes significance to these issues and responds to the criticism that institutional investors are excessively focused on the short

173. Id.

174. See Hanne Søndergaard Birkmose, European Challenges for Institutional Investor Engagement - Is Mandatory Disclosure the Way Forward, 11 EUR. CHARTER FUNDAMENTAL RTS. 214, 236 (2014); Hopt, supra note 19, at 177; see also Rock supra note 9 , at $379-81$.

175. Strand, supra note 18 , at 38.

176. McCahery et al., supra note 82 .

177. Hopt, supra note 19, at 153, 177.

178. See, e.g., F. William McNabB III, Vanguard, An Open Letter to Directors of Public COMPANIES Worldwide 2 (2017), https://about.vanguard.com/investmentstewardship/governance-letter-to-companies.pdf [https://perma.cc/EQJ6-7B7N]; Fink, supra note 80 .

179. See Lund, supra note 5, at 528 ("[T] vote as a signal of poor quality, especially when all other funds continue to highlight their governance abilities.").

180. See supra text accompanying note 163. 
term. ${ }^{181}$ This virtuous cycle can prove even stronger in the EU where pension funds, insurance companies, and other institutional investors are by far the most important clients for the European asset management industry. ${ }^{182}$

Moreover, this positive effect would not be limited by the fact that engagement policy disclosure is adopted on a "comply or explain" basis. ${ }^{183}$ The requirement to illustrate the reasons that led to a deviation from best standards represents a significant incentive to comply with disclosure obligations, considering the reputational consequences of noncompliance. ${ }^{184}$ Thus, the disclosure of the engagement policy according to the SHRD II, Article 3c, can alleviate, at least in part, the effects of collective action along with the free-rider problem inducing institutional investors to abstain from engagement. Presumptively, then, "reputational competition" within the investment industry is a factor that can induce most institutional investors to increase their efforts in engagement with investee companies and to bear the related costs. ${ }^{185}$ In other words, reputational incentives can induce institutional investors to incur the engagement-related costs that they could save by free-riding on other investors' engagement. ${ }^{186}$

Therefore, the rise of passive investing may favor the achievement of the EU Commission's objectives in the area of listed company corporate governance: greater involvement of institutional investors in the corporate

181. See Lund, supra note 5, at 527-28 ("The fact that the Big Three increasingly tout their governance expertise in their marketing materials, in speeches, and in op-eds indicates that they believe that creating an appearance of governance expertise will help them win clients." (footnotes omitted) (citations omitted)); Fisch et al., supra note 3, at 13 ("[F]und sponsors may see governance engagement as a branding or marketing tool that provides them with another dimension on which to compete for assets.").

182. See Eur. Fund \& Asset MGMt. Ass'N, supra note 48, at 29-33.

183. David Hicks, Corporate Governance: One Size Does Not Fit All, QuOTED COMPANIES ALLIANCE (May 24, 2018), https://www.theqca.com/information-centre/corporategovernance/150331/corporate-governance-one-size-does-not-fitall.thtml [https://perma.cc/ H2C2-SE9E].

184. See Madsen, supra note 28, at 153-54.

185. See BIOY ET AL., supra note 38, at 20 ("All in all, it is fair to say that most index managers have no intention to free-ride with respect to engagement. All but one of the surveyed firms have plans to intensify their efforts in this area and bear the associated costs. This is because they see engagement as an important and integral part of their stewardship responsibilities and increasingly as something that clients expect from-in the words of one surveyed manager - a 'grown-up' asset-management organization.”).

186. For example, Fidelity International, a small institutional investor - not to be confused with Fidelity Investments - recently created the new position of stewardship and sustainable investing head. Eugenia Jimenez, Fidelity Names Head of ESG Team, INV. EUR. 1-2 (Jan. 15, 2018), http://www.investmenteurope.net/regions/fidelity-names-headesg-team/ [https://perma.cc/D84Q-QT6Y]; see also Sarah Gordon, UK Fund Managers Commit to Increasing Social Impact Investment, FIN. TIMES (Mar. 23, 2018), https:// www.ft.com/content/167c7164-2dc1-11e8-9b4b-bc4b9f08f381 ("Social impact is moving up investors' agenda as companies face increasing scrutiny over their behaviour towards all stakeholders."). 
governance of investee companies, a shift towards long-term value creation, and greater attention to the nonfinancial performance of companies, which include environmental, social and governance factors. Accordingly, if this is the case, there would not appear to be any need for any regulatory reaction by the EU Commission to the rise of passive investing.

However, such a conclusion is excessively positive and is not in line with the evidence mentioned above, which demonstrates some of the drawbacks of passive investors' voting and engagement and raises doubts as to whether these investors have any interest in effectively overseeing investee company activities. In particular, because of their investment strategy and the related fee structure, passive investors have an interest in keeping engagement- and voting-related costs low. For this reason, in many cases they vote according to predefined voting policies, without carrying out any analysis on the specific company. ${ }^{187}$ Second, and more importantly, passive investors mainly focus on ESG issues requiring lowcost interventions although they refrain from engaging in high-cost governance activities such as monitoring of M\&A or presenting slates of candidates for election to the board of directors. ${ }^{188}$ Consequently, given the collective action problems facing the investment industry, active fund managers have no more incentive to invest in stewardship than passive investors do because investment does not lead to any significant improvement in their relative performance. ${ }^{189}$

This appears to have a paradoxical consequence. The rise of investors focused on long-term value creation and ESG issues called for by the EU Commission may not result - to use the words of the Commission itselfin an effective and exhaustive system of "checks and balances between the different organs and different stakeholders," 190 especially in relation to operations such as M\&A or related-party transactions that are more likely to impinge upon the value of the company and its long-term perspectives.

However, this appears to demonstrate that the main disincentive for engagement by passive and active institutional investors is not shorttermism but cost. Although the EU Commission is aware that costs are an

187. See supra Section III.A.

188. See supra note 115 and accompanying text; see also Bebchuk et al., supra note 3 , at 101 ("[L]arge investment managers generally avoid submitting shareholder proposals, nominating directors to the boards of corporations, or conducting proxy contests.").

189. See Bebchuk et al., supra note 3, at 99.

190. SHRD II, supra note 17, at 3. 
obstacle to engagement, ${ }^{191}$ the regulatory actions hitherto adopted at the $\mathrm{EU}$ and Member State level may favor a reduction in engagement costs. As correctly noted by Madsen, although the SHRD, I and II, introduced measures with the aim of lowering the costs of engagement-including, inter alia, easier access to proxy voting, electronic general meetings, the provision of information to shareholders prior to the general meeting, and record date - the EU Commission cannot "control the 'in-house' costs that institutional shareholders incur when engaging in shareholder activism. Consequently, the effects on shareholder engagement that a further focus on shareholders' cost frame could result in only seem minor."192

\section{Activating Passive InVEstors By Reducing ENGagement- RELATED COSTS: A CONCEPTUAL FRAMEWORK FOR POTENTIAL REGULATORY STRATEGIES}

Therefore, a case for reconceptualizing the EU approach to institutional investor engagement is apparent by acknowledging that the true limit on more effective institutional investor engagement is cost and not the short investments' timescale. Against this background, building on the analysis of the EU corporate governance system, this Part will outline a conceptual framework - easily transplantable into various countries, including the United States-for the potential regulatory strategies that may be adopted to incentivize passive index funds managers and, more generally, institutional investors to play a more effective oversight role over investee companies.

\section{A. Setting a More Favorable Legal Environment for Activist Investors}

The previous analysis demonstrates that active and passive institutional investors do not have sufficient incentives to scrutinize investee companies' business strategies and to commit to costlier engagement. Costlier interventions, such as the monitoring of M\&A or presenting slates of candidates for election to the board of directors, may only be promoted by other types of institutional investors, particularly by hedge funds. As noted above, hedge fund managers have stronger incentives to invest in stewardship becausein contrast to active and passive mutual funds - they are able to capture a significant share of the value increase generated by governance-related campaigns. ${ }^{193}$ Therefore, to promote more effective shareholder engagement,

191. EC Green Paper, supra note 171, at 11 (noting that costs are a barrier to engagement); see also Birkmose, supra note 174, at 218, 234; Madsen, supra note 28, at $156-57$.

192. Madsen, supra note 28, at 157.

193. See supra text accompanying note 133 . 
the EU Commission could focus more on the role of activist hedge funds as a catalyst for institutional shareholders. This would align with what already occurs in the United States, where hedge funds play a central role, ${ }^{194}$ and would result in a convergence between the European and American approaches to institutional shareholder engagement.

However, the current EU legislation includes measures that could discourage hedge fund activism. In particular, the rules on disclosure of major holdings have relevant impact on hedge funds' activity. As Alessio Pacces noted, the applicable law on both sides of the Atlantic are not dissimilar: both United States and EU lawmakers have set a 5\% beneficial ownership threshold. ${ }^{195}$ However, the EU legal environment disfavors hedge fund activism. First, according to Article Fourteen of the Transparency Directive, the issuer must be notified within "four trading days," 196 although the United States provides a ten-day time window. ${ }^{197}$ Second, EU member states are allowed to set lower thresholds and shorter time windows. ${ }^{198}$ "For example, the threshold is 3\% in the UK, Italy, and the Netherlands, whereas the time window is 2 days in the UK." 199 In addition, the shareholder identification regime set out in the SHRD II, Article $3 \mathrm{a},{ }^{200}$ may curb hedge fund activism in a similar manner to the obligations to disclose major holdings. ${ }^{201}$ Both the disclosure of major holdings and the rules on

194. See supra text accompanying note 132 .

195. Pacces, supra note 138, at 18.

196. Directive 2004/109, of the European Parliament and of the Council of 15 December 2004 on the Harmonisation of Transparency Requirements in Relation to Information About Issuers Whose Securities Are Admitted to Trading on a Regulated Market and amending Directive 2001/34/EC, 2004 O.J. (L 390) 38, 49 [hereinafter Transparency Directive].

197. Pacces, supra note 138, at 18 (citing 17 C.F.R. $§ 240.13 d-1$ (2002)).

198. See id.

199. Id.; see also Gilson \& Gordon, supra note 8, at 905; Alexandros Seretakis, Hedge Fund Activism Coming to Europe: Lessons from the American Experience, 8 BROOK. J. CORP. FIN. \& COM. L. 438, 461 (2014). For a comprehensive overview of the EU member states' rules concerning the notification of major shareholding, see generally EUROPEAN Sec. \& Mkts. Auth., Practical Guide: National Rules on Notifications of Major Holdings Under the TRANSPARENCy DiRective (2017), https://www.esma.europa.eu/ sites/default/files/library/practical_guide_major_holdings_notifications_under_transpare ncy_directive.pdf [https://perma.cc/VDT3-DXPT].

200. See SHRD II, supra note 17, at 13-14.

201. See Pacces, supra note 138, at 17-19. For an overview of the shareholder identification and communication systems in EU member States, see EUROPEAN SEC. \& MKTS. AUTH., REPORT ON SHAREHOLDER IDENTIFICATION AND COMMUNICATION SYSTEMS 18-41 (2017), https://www.esma.europa.eu/sites/default/files/library/esma31-54-435_ 
identification can impact hedge fund activity by forcing hedge funds to disclose the purchase of target company stocks at an early stage. ${ }^{202}$ This prevents hedge funds from purchasing undervalued stock of the target when the hedge fund's intentions are not yet known and selling them at a higher price if its campaign is successful. ${ }^{203}$

Against this background, it must be asked whether the rise of passive investing could result in a reconsideration of these rules in a manner more favorable to activism by increasing the shareholding threshold and extending the time window for complying with disclosure duties. ${ }^{204}$ The EU Commission should, in particular, reconsider that " $[\mathrm{t}]$ he benefits of tighter disclosure rules in terms of improved market transparency and fairness must be weighed against the costs imposed on shareholders and companies as a result of a reduction in the incidences of activist activities."205

A more favorable legal environment for activist hedge funds could enable them, at least in part, to overcome the limits on engagement posed by passive index fund managers and nonactivist institutional investors, who tend to become involved only in low-cost engagement activities. ${ }^{206}$ In keeping with the view that considers cooperation between institutional investors and activist hedge funds a prerequisite for enhancing the efficacy of shareholder engagement, activist hedge funds, with the necessary means and incentives, could promote costly engagement initiatives, such as the scrutiny of M\&A and related-party transactions or the presentation of slates of candidates for election to the board of directors. ${ }^{207}$ In keeping with their rationally reticent approach, active and passive mutual fund managers would only have to assess whether to support the activists' interventions with their votes. ${ }^{208}$

However, at least at the present time, it appears unlikely that there will be any change in the corporate governance strategy of the EU Commission along these lines. The EU Commission does not consider activist hedge funds as the right kind of owners and has instead opted for institutional

report_on_shareholder_identification_and_communication.pdf [https://perma.cc/UHB4$8 \mathrm{VPY}]$.

202. See Pacces, supra note 138 , at 17-20.

203. See Gilson \& Gordon, supra note 8, at 904-12; Pacces, supra note 138, at 17 18; Seretakis, supra note 199, at 463-64.

204. See Seretakis, supra note 199, at 466.

205. Id. at 467 (citing Lucian A. Bebchuk \& Robert J. Jackson, Jr., The Law and Economics of Blockholder Disclosure, 2 HARV. Bus. L. REV. 39, 59-60 (2012))

206. See Bebchuk et al., supra note 3, at 106.

207. See, e.g., Gilson \& Gordon, supra note 8, at 867, 897 ("Activist investors specialize in monitoring portfolio company strategy and formulating alternatives when appropriate for presentation to the institutional investors; in turn, institutional investors specialize in portfolio management and in evaluating proposals presented by activist investors.").

208. See id. at 867. 
investor driven engagement. ${ }^{209}$ Furthermore, a relaxation of the disclosure regime of major shareholdings is hardly feasible from a political standpoint, given that the EU Commission views these disclosure duties as one of the pilasters of the financial market and investor protection system. ${ }^{210}$

Aside from these political obstacles, one must remember that hedge fund-driven engagement has its potential drawbacks. First, as John Coffee noted, activism entails significant agency costs and several areas of conflict of interest with those of other shareholders. ${ }^{211}$ Second, as activist hedge funds own only a small proportion of the equity market compared with the holdings of institutional investors, they are expected to intervene only in a limited number of companies. ${ }^{212}$ In particular, "[a]ctivist hedge fund managers have incentives to spend on stewardship only when the governance-generated value increases likely to result are especially large."213 Therefore, activist hedge funds are willing to intervene only "when governance failures have led to substantial operating underperformance." 214 Absent these conditions, hedge funds do not have any incentives to intervene and fail to act as monitors of management. Accordingly, it is likely that hedge fund-driven engagement will not detect any corporate governance failure that does not give rise to underperformance on a scale sufficient to attract the attention of hedge funds.

Moreover, there are doubts regarding the efficacy of interaction between hedge funds and passive index funds. Although, given the size of their shareholdings, the Big Three are often decisive in the success of activist

209. Pacces, supra note 138, at 17.

210. See Transparency Directive, supra note 196, at 40 ("The public should be informed of changes to major holdings in issuers whose shares are traded on a regulated market situated or operating within the Community. This information should enable investors to acquire or dispose of shares in full knowledge of changes in the voting structure; it should also enhance effective control of share issuers and overall market transparency of important capital movements.").

211. John C. Coffee, Jr., The Agency Costs of Activism: Information Leakage, Thwarted Majorities, and the Public Morality 15-25 (European Corp. Governance Inst., Working Paper No. 373/2017, 2017), https://ecgi.global/sites/default/files/working_papers/ documents/finalcoffee.pdf [https://perma.cc/XSQ4-E4RS] (mentioning different ways activists can extract value from investee companies, including through the reimbursement of the expenses incurred in connection with the engagement-and the access to materialof nonpublic information).

212. Sharon Hannes, Super Hedge Fund, 40 Del. J. CORP. L. 163, 168 (2015).

213. Bebchuk et al., supra note 3 , at 106.

214. Id. 
campaigns, ${ }^{215}$ it is uncertain whether they perform this decisive role in an appropriate manner. ${ }^{216}$

First, empirical evidence shows that most forms of activist engagement are resolved through private settlement negotiations between the activists and company management, which often results in activists winning board seats. ${ }^{217}$ However, such settlements frequently do not involve leading passive investors, especially the Big Three, which "perceive themselves as having been excluded by these private agreements from the role they deserve as "permanent shareholders.",218

Second, it is uncertain whether leading passive fund managers are interested in monitoring activists' initiatives. On the one hand, given their interest in keeping fees low and the collective action problems affecting them, ${ }^{219}$ it is uncertain whether passive index funds have any incentive to scrutinize the activist proposals adequately. On the other hand, because they are permanent shareholders, they should have an interest in monitoring activist interventions to prevent activists' proposals that are not aligned with long-term objectives or that could destroy the company's value. ${ }^{220}$

Although the Big Three support activists with increasing frequency 221 and invest resources to evaluate the merit of activist intervention, the available anecdotal and empirical evidence concerning the conduct of the Big Three in contested decisions is inconclusive. ${ }^{222}$ Additionally, especially under the SHRD II, institutional investors could "support the engagement

215. See supra note 138 and accompanying text.
216 . See Pacces, supra note 138 , at $14-16$.
217 . See LAZARD, supra note 156 , at 5 (showing that, in 2018 , only 18 board seats

217. See LAZARD, supra note 156 , at 5 (showing that, in 2018, only 18 board seats
(see also Lucian A. Bebchuk et al., Dancing with Activists 9-13 (Columbia Bus. Sch., Research Paper No. 17-44, 2017); Coffee, supra note 211 , at 9-15.

218. Coffee, supra note 211, at 14; see also Abe Friedman, Responding to Concerns Regarding the Protection of the Interests of Long-Term Shareholders in Activist Engagements, HARV. L. SCH. F. ON CORP. GOVERNANCE \& Fin. REG. (Oct. 10, 2018), https:/corpgov.law.harvard.edu/2016/10/17/responding-to-concerns-regarding-the-protectionof-the-interests-of-long-term-shareholders-in-activist-engagements/ [https://perma.cc/ 4XEB-GNRU]. Compare Bebchuk et al., supra note 217, at 26 (showing directors appointed through a settlement agreement do not receive lower voting support than incumbent directors or those who join the board during nonsettlement campaigns), with Coffee, supra note 211 , at 15 (noting that the Bebchuk study cannot be considered exhaustive because it covers results only through 2011, while the Big Three began voicing their concerns and criticisms only more recently in 2015 and 2016, when the number of board seats won through settlements further increased). See Fisch et al., supra note 3, at 23-24 (describing the role of passive investors in relation to active investors).

219. See Lund, supra note 5, at 500; Bebchuk et al., supra note 3, at 98.

220. See supra notes 139-40 and accompanying text.

221. See supra note 148 and accompanying text.

222. See supra notes 160-61 and accompanying text. 
of an underperforming company in the name of ESG goals, whether or not the activist's strategy is effectively a long-term one."223

Therefore, interaction among hedge funds and passive index funds is an area of research that deserves greater attention. Specifically, it is essential to carry out additional empirical analysis to test the tendency of hedge funds to seek passive investors' support by adopting more long-term oriented strategies and paying increasing attention to ESG issues. ${ }^{224}$ If further analysis confirms that interaction with passive index funds could effectively discipline activist hedge funds, the EU Commission should probably reconsider its skeptical approach to hedge fund activism.

\section{B. Eliminating Passive Fund Voting to Activate Other Nonactivist Institutional Investors?}

Should - as is likely at least over the short term - the EU Commission not intend to rely on activist hedge funds and prefer to maintain its institutional investor-driven strategy, it is necessary to set out measures to promote more effective and costly engagement with passive index funds. ${ }^{225}$

Thus far, a detailed investigation of corporate-governance consequences of passive investing has proposed restricting passive funds from voting on their shares. ${ }^{226}$ This proposal reasons that passive fund managers be treated like derivative holders for the purposes of voting because passive funds attract investors on the basis of their ability to track an index. ${ }^{227}$ Therefore, voting will increase costs for investors without producing corresponding benefits and therefore would arguably breach the fund's fiduciary duty. ${ }^{228}$ Moreover,

223. Pacces, supra note 138, at 21.

224. See supra note 161.

225. As said above, actively managed mutual funds have limited incentive to actively engage with investee companies as well. See supra text accompanying note 9 . Therefore, the following analysis generally fits not only for passive index funds but for mutual funds overall. However, for the sake of simplicity, I will refer below only to passive index funds.

226. See Lund, supra note 5, at 530-31 ("[V]oting power for 'non-routine' matters [c]ould flow through to the passive fund's investors in a phenomenon known as 'passthrough voting.' [Therefore], a rule could provide for pass-through voting on non-routine matters, such as a default, allowing investors the option of reassigning the proxy back to the fund." (footnote omitted)). As retail investors participating in mutual funds would be unlikely to vote because of collective action problems, such a solution could provide a benefit similar to that of passive fund voting elimination.

227. Id. at 511 .

228. Id. at 529 ("The rule could employ a presumption that any fund that uses indexing as an investment strategy is a passive fund. That presumption could be rebutted, allowing the passive fund to be 'certified' for voting, if the fund showed that its strategy 
the elimination of passive fund voting would be beneficial because it would "preserve the influence of informed investors by giving each active investor a proportional increase in voting power." 229

However, this proposal seems to present some potential drawbacks. First, eliminating the influence of passive investors within the governance of investee companies seems too radical an approach, which does not adequately consider available studies concerning corporate governance implications of passive investing. ${ }^{230}$ Second, the available evidence shows that passive investors may positively affect aspects of corporate governancedirectors' independence, board diversity, disclosure of climate risks - that require low-cost intervention. ${ }^{231}$ In addition, were passive investors deprived of voting rights, this would undermine their potential positive impact on strategies of other institutional investors, including hedge funds, inducing them to pursue long-term oriented approaches and to consider ESG issues. ${ }^{232}$ Finally, it appears reasonable to expect that in countries such as continental Europe, where activism is still limited, this proposal would have the unintended consequences of making the shareholder base even more passive and weakening shareholders' oversight role. In fact, a regulatory strategy of this type does not affect the costs of engagement and does not incentivize managers of actively managed mutual funds to scale up their engagement activities. $^{233}$

incorporated meaningful portfolio company research - including ongoing monitoring and fundamental analysis - and that its investment in governance is above a certain threshold (based on the fund's size).").

229. Id. at 529-30.

230. See supra Part III.

231. See supra note 108 and accompanying text.

232. See supra note 179 and accompanying text; see also Jonathan Litt, Why All Shareholder Voices, Even Passive Ones, Matter, N.Y. TIMES (July 20, 2017), https://nyti.ms/ 2ttNiRV [https://perma.cc/GXV6-LMAQ] ("[P] assive funds will increasingly be willing to engage with active investors. This dialogue will help passive investors better use the knowledge and experience fundamental investors can bring through their years of engagement with these companies and the individuals that run them.").

233. See Lucian Bebchuk \& Scott Hirst, Are Active Mutual Funds More Active Owners than Index Funds?, HARV. L. Sch. F. ON CORP. GOVERnANCE \& FIN. REG. (Oct. 3, 2018), https://corpgov.law.harvard.edu/2018/10/03/are-active-mutual-funds-more-active-ownersthan-index-funds/ [https://perma.cc/SP4F-BLLU] ("[W]hile we recognize the current shortcomings of index fund stewardship, we caution against any approach that gives up on such stewardship and proposes to curtail the influence of index funds in favor of increased influence of actively managed funds."). 


\section{Shifting Passive Funds' Engagement Costs to Ultimate Investors or Investee Companies}

Given the elimination of passive fund voting seems unlikely to trigger more effective engagement by other nonactivist institutional investors, ${ }^{234}$ other policy options aimed at stimulating passive investor involvement in the corporate governance of investee companies will be considered.

Because a reduction in engagement costs is the key incentive for passive investors to play a more active corporate governance role, there is no doubt that any regulatory intervention that solely seeks to extend the investment timeframe, such as those introduced in France ${ }^{235}$ and Italy ${ }^{236}$ concerning tenure voting and loyalty dividends, will not alter the conduct of passive index fund managers. ${ }^{237}$ Because passive investors as permanent shareholders cannot sell shares included in the reference index, they commit to the long term - irrespective of the level of their voting rights - and may forego loyalty benefits simply because of portfolio rebalancing. ${ }^{238}$ Consequently, it is not surprising that passive funds' managers adhere to the "one share one vote - one dividend" principle and are generally against the introduction of loyalty-shares or loyalty-dividends. ${ }^{239}$

Therefore, policy interventions that are aimed at reducing the costs of engagement are key to incentivizing passive index funds to play a more

234. Id. (" $[\mathrm{I}] \mathrm{t}$ is important to recognize that there is evidence that many active funds are, to varying extents, 'closet indexers' whose holdings substantially overlap with their benchmark index, deviating only by limited underweighting and overweighting of certain stocks.").

235. See Loi 2014-384 du 29 mars 2014 visant à reconquérir l'économie réelle [Law 2014-384 of March 29, 2014 Aiming to Reclaim the Real Economy], JOURNAL OfFICIEL De la Republique FranÇaise [J.O.] [OfFicial Gazette of France], Mar. 27, 2014, art. 7.

236. For loyalty dividends and loyalty shares, see Article 127-quarter and Article 127-quinqueies of Decreto Legislativo 24 febbraio 1998, n.58, in G.U. Mar. 26, 1998, n.71 (It.) For an overview of national provisions concerning loyalty shares, see Hopt, supra note 19, at 174; Ventoruzzo, supra note 23 , at 5-9, 13-16.

237. See Lynne L. Dallas \& Jordan M. Barry, Long-Term Shareholders and TimePhased Voting, 40 DEL. J. CoRP. L. 541, 627-28 (2016) (finding no evidence that time phased voting increased shareholdings by institutional investors with long-term investment horizons or decreased shareholdings by institutional investors with short-term investment horizons); see also Alex Edmans, The Answer to Short-Termism Isn't Asking Investors to Be Patient, HARV. Bus. REV. (July 18, 2017), https://hbr.org/2017/07/theanswer-to-short-termism-isnt-asking-investors-to-be-patient [https://perma.cc/QEN8-XT3Z].

238. See Pacces, supra note 136, at 199, 214.

239. BlackRock, Proxy Voting Guidelines for European, Middle Eastern AND AFRICAN SECURITIES 21 (2018), https://www.BlackRock.com/corporate/literature/factsheet/blk-responsible-investment-guidelines-emea.pdf [https://perma.cc/73EN-8FTC]. 
effective stewardship role in investee companies. To this end, one initial regulatory approach could be to allow institutional investors to transfer engagement costs - even if only expenses related to very costly engagements - to ultimate investors or to investee companies.

Institutional investors can already - within the limits of the law - charge engagement costs to their investment funds, thereby passing these costs on to the funds' beneficial investors. ${ }^{240}$ Although some investors who are sensitive to corporate governance issues may accept an increase in fees associated with stewardship costs, ${ }^{241}$ this solution features significant drawbacks. First, it may increase costs for ultimate investors. ${ }^{242}$ Second, it could favor the exploitation of engagement initiatives by institutional investors. ${ }^{243}$ Third, such a solution would not resolve the collective action problems affecting the investment industry: it would lead to an increase in the fee for the engagement fund while not significantly improving its performance compared to other funds holding the same company in their portfolio, thereby resulting in a loss of clients to competitors. ${ }^{244}$

Alternatively, to incentivize institutional investors to exercise more effective oversight over the management of investee companies, the engagementrelated costs borne by institutional investors could be charged to the company, provided that the shareholder intervention is beneficial. ${ }^{245}$ More specifically, "the benefit for the company could be demonstrated by a sustained (at least a year) boost in stock price following the intervention [and the shareholder could] receive costs associated with that intervention, limited to research costs incurred no more than one month prior to the intervention." 246 However, this policy option raises questions. First, because it would enable shareholders to recover only part of the costs associated with their interventions, it is questionable whether this solution could effectively incentivize passive index funds to make more costly engagements. ${ }^{247}$ Second, it would be difficult to determine the benefits for the company because any increase in the stock price over the period following the institutional investor intervention may not necessarily correlate with it. ${ }^{248}$

240. See Bebchuk et al., supra note 3, at 108.

241. Lund, supra note 5, at 531.

242. ROGER. M BARKER \& IRIS H.-Y. ChIU, CORPORATE GOVERNANCE AND INVESTMENT MANAGEMENT 177 (2017).

243. Id. at 178 .

244. See id. at 288; Bebchuk et al., supra note 3, at 99.

245. See Lund, supra note 5, at 534-35.

246. Id. at 535 .

247. Id.

248. Id. (noting that, because it is difficult to quantify the benefit resulting from the shareholder's intervention, it is hard to design an incentives' regime providing the activist shareholder with a benefit-related monetary reward). 
Therefore, this solution could result in the company being charged with costs of engagements that do not have any positive effects or that are even harmful.

\section{Redistributing Engagement Costs by Favoring Institutional Investor Coordination}

The above suggests there are no solutions capable of significantly reducing the engagement costs borne by passive funds - and by nonactivist institutional investors in general. Furthermore, a partial reduction in costs may not be sufficient because collective action problems lead passive index funds to refrain from engaging with investee companies. ${ }^{249}$ Thus, a different approach must be preferred. Instead of attempting to reduce the costs of engagement, it is preferable to promote the redistribution of these costs between active and passive institutional investors. In this regard, incentivizing collective engagement could be key. ${ }^{250}$ This means engagement costs would be shared between the institutional investors that collectively undertake engagement activities, thereby overcoming possible action problems. ${ }^{251}$

This proposal does not seek to radically change the engagement practices of passive investors. These investors would continue to adopt standardized voting policies and to rely largely on proxy advisory services for routine matters. ${ }^{252}$ On the other hand, the redistribution of costs favored by collective engagement may promote more proactive engagement by them in nonroutine issues, such as proxy contests or M\&A and related-party transactions -if they experience the redistribution of costs effected by collective engagement. ${ }^{253}$ Additionally, collective engagement can incentivize passive and active institutional investors to adequately scrutinize activists' proposals. In this way, interaction between activist and nonactivist investors can render more effective shareholder engagement.

249. Id. at 500 .

250. See Birkmose, supra note 174, at 243; Ruth Sullivan, Collective Engagement is Picking up Steam, Fin. TIMES (Nov. 8, 2009), https://www.ft.com/content/0231ac18-cb0711de-97e0-00144feabdc0.

251. See OECD, The Role of Institutional Investors in Promoting Good CORPORATE GOVERNANCE 38 (2011), https://www.oecd.org/daf/ca/49081553.pdf [https://perma.cc/ 9RZD-9377] ("The ability for institutional investors to co-operate is fundamental to resolving the free rider problems ....").

252. See Enriques \& Romano, supra note 75, at 15.

253. See OECD, supra note 251, at 13,38 . 
The collective engagement of institutional investors can be organized in different ways, and some proposals have already been made in this area. For example, Sharon Hannes sets out a model of collective engagement based on a contractual arrangement among a broad group of institutional investors and a task force of financial experts called "super hedge fund." 254 Such an agreement would have a two-fold advantage. First, it would make it possible to resolve collective action problems and conflicts of interest that restrain institutional investors from engagement by splitting engagement costs among investors adhering to the arrangement. ${ }^{255}$ Second, it would counter the claims of short-termism raised against current hedge fund activism. ${ }^{256}$ According to this proposal, "an existing well-connected organization, such as ISS or the Council of Institutional Investors, or alternatively, a not-for-profit organization [established specifically] for this purpose," would draft the agreement and serve as a clearing house for the operation. ${ }^{257}$ The team of experts brought together by the parent organization would have significant powers and would be free to act on its own initiative. Specifically, "[t]he task force would be relatively free to identify the target and design an activism strategy; it would also be able to initiate and manage activist campaigns against the target company." ${ }^{258}$ Furthermore, to allow institutional investors to effectively monitor the task force's activities, the agreement could stipulate any measures requiring pre-approval by the member institutions with a stake in the target company. ${ }^{259}$

254. Hannes, supra note 212, at 163, 182-89.

255. Id. at 182-83 ("The standard agreement would provide crucial two-tier funding for the task force's activities. Tier-one funding would be quite minimal and used to support the task force before it engages in activism.... However, once the task force begins to zero in on a target, it would become entitled to call for additional and much more substantial tier-two funding. This capital call should be sufficient to cover major possible expenses such as proxy fight costs, litigation, and public and investors relations campaigns. Most importantly, the source of funding for the two tiers would differ as follows: the lowtier-one funding would be provided by all institutional investors that have signed an agreement with the task force. [By contrast,] funding called for after the task force has zeroed in on a target would not come from all the institutional investors. Rather, the tiertwo funding would be borne solely by the institutional investors that invest in the specific potential corporate target and pro-rata to their holdings in the target." (footnotes omitted)).

256. See id. at 189-99.

257. Id. at 199 (footnote omitted).

258. Id. at 184 ("[T] the funding from its members, such as public relation campaigns and litigation against management. The task force could also initiate a proxy fight in which it would have an advisory role (but would not be given a proxy to engage in any action that requires the vote of the institutional investors).").

259. Id. at 185 
The United Kingdom has already adopted a similar approach. Based on the recommendations set forth by the UK equity markets review, undertaken by Professor John Kay and promoted by the UK Government, ${ }^{260}$ an Investor Forum was established in 2014 with the aim of promoting the collective engagement of institutional investors. ${ }^{261}$ Currently, the Investor Forum operates as a member-founded nonprofit organization and has its own team of corporate governance and financial experts. ${ }^{262}$ At present, there are forty-two institutional investors in the Investor Forum, of which fourteen are international, accounting for around 29\% of FTSE All Share market capitalization. ${ }^{263}$ Between 2015 and 2017, the Forum assessed twenty-eight collective engagement initiatives and engaged with eighteen. ${ }^{264}$ The range of participants in collective engagement initiatives is between two and fifteen, representing company market capitalization of between $7 \%$ and $50 \%{ }^{265}$

In line with the recommendations of the Kay Review, the Investor Forum takes a more flexible approach compared to that set out in the Hannes proposal. ${ }^{266}$ The collective engagement framework elaborated by the Investor Forum states, among other things, that " $[\mathrm{m}] \mathrm{embers}$ retain full voting and other investment rights in respect of their shareholdings" and are free to "choose[] to participate in an [e]ngagement involving a [c]ompany in which [they are shareholders or] to opt out of an [e]ngagement at any time."267 Additionally, Forum members are "encouraged to . . . continue their direct interaction with [c]ompanies" falling beyond the purview of the Forum. ${ }^{268}$

260. See John Kay, The Kay Review of UK Equity Markets and Long-Term DECISION MAKING 51-53 (2012), https://assets.publishing.service.gov.uk/government/ uploads/system/uploads/attachment_data/file/253454/bis-12-917-kay-review-of-equitymarkets-final-report.pdf [https://perma.cc/8AJG-3U4D].

261. BARKER \& CHIU, supra note 242, at 175.

262. See generally INV'R FORUM, REVIEW 2017 (2018), http://www.investorforum. org.uk/wp-content/uploads/2018/07/Annual-review-2017.pdf [https://perma.cc/JV88-X8TZ].

263. Membership Summary, INV. F. (Oct. 1, 2018), https://www.investorforum. org.uk/membership-summary/ [https://perma.cc/C6T7-VH52].

264. INV'R FORUM, supra note 262, at 2.

265. Id. at 5 .

266. See KAY, supra note 260, at 51 ("Rather than a formal, static body, we anticipate that the membership and format of the forum would be sufficiently flexible to accommodate both general discussion of issues of company strategy and corporate governance, and also specific issues arising at particular companies.").

267. InV'r Forum, COllective Engagement Framework: Summary 3 (2016), https://docs.wixstatic.com/ugd/1cfle4_2982e569543345c583d8db5707281fb6.pdf [https:// perma.cc/ZW7V-ASKN].

268. Id 
According to this flexible approach, both affiliated institutional investors and listed companies in which investors hold a stake can propose initiating an engagement. ${ }^{269}$ The Forum's team then evaluates the proposal and, once it has determined that the proposal is consistent with the Forum's engagement framework, the team engages in consultation with the major shareholders of the company to determine the level of member support for the proposed engagement. ${ }^{270}$ The Investor Forum proceeds with the engagement if, and only if, the proposal reaches an adequate level of support. ${ }^{271}$

Although the UK approach to collective engagement seems capable of favoring more effective and proactive institutional investor engagement, ${ }^{272}$ it is unclear whether institutional investors will be willing to pay fees to become members of the Investor Forum or another similar institution. In fact, institutional investors and especially passive index funds might prefer freeriding on the initiatives of other investors.

However, although the benefits of collective engagement for passive investors are more limited because of the presence of internal stewardship teams as well as the fact that each portfolio company has a lower relative weight, anecdotal evidence and academic analysis suggests that collective engagement can also incentivize passive index fund managers to engage in costlier engagement activities. For example, as one of the members of the Investor Forum, BlackRock participates "under the umbrella of the Collective Engagement Framework of the Investor Forum . . . in collaborative engagements with other shareholders where concerns have been identified by a number of investors." 273 More generally, as observed by Luca Enriques and Alessandro Romano, network theory could explain the participation of institutional investors in collective engagement initiatives. ${ }^{274}$ In particular, they argue that "if the potential gains from cooperating are large enough, the relevant players might decide to invest resources in the creation of a public monitoring institution that increases the chances that those patterns of cooperative behavior are sustained across time."275 Additionally, as the costs of setting up a monitoring institution borne by each institutional investor are likely to be minuscule compared to the value of its portfolio, "if cooperation ... increases the value of the portfolio assets, however marginally, the benefits derived from cooperation would most likely

269. See id. at 5 .

270. Id.

271. See id.

272. See BARKER \& CHIU, supra note 242, at 173.

273. BLACKROCK, supra note 239, at 2; see also Sullivan, supra note 250.

274. Enriques \& Romano, supra note 75 , at 35.

275. Id. 
outweigh the costs borne by each investor to establish the monitoring institution." 276

Nevertheless, the dissemination of collective engagement initiatives like those promoted by the Investor Forum still appears limited in the EU, which could be because of the legal concerns raised by coordination between institutional investors. ${ }^{277}$ In particular, institutional investors who engage collectively could be regarded as parties "acting in concert," with the result that collective engagement could trigger the mandatory bid threshold. ${ }^{278}$ There is also a risk that collective engagement could entail the exchange of inside information between the company and the institutional investors involved in the engagement or among the latter. ${ }^{279}$

Concerning concerted action, in response to the concerns raised by the Commission's 2011 Green Paper, ${ }^{280}$ the ESMA identified a "White List" of certain activities in which shareholders might wish to engage for the purpose of exercising good corporate governance without seeking to acquire or exercise control over the company. ${ }^{281}$ Therefore, when shareholders engage in any activity included on the White List, their cooperation should not be considered concerted action, and shareholders would not risk triggering the mandatory bid threshold. ${ }^{282}$ However, the ESMA provides investors with only limited protection, ${ }^{283}$ for it also states that "national competent authorities, when determining whether cooperating shareholders are acting in concert, decide each case on the basis of its own particular facts." 284

276. Id. at 36; see also Hannes, supra note 212, at 183.

277. See McCahery et al., supra note 82, at 2920-22; see also OECD, supra note 251, at 39; Birkmose, supra note 174, at 244.

278. BARKER \& CHIU, supra note 242, at 174.

279. See Giovanni Strampelli, Knocking at the Boardroom Door: A Transatlantic Overview of Director-Institutional Investor Engagement in Law and Practice, 12 VA. L. \& BUS. REV. 187, 211-12 (2018).

280. See EC Green Paper, supra note 171, at 14.

281. EuRopean SEC. \& MKTS. Auth., Public Statement: INFORMATION ON SHareHOldER COOPERATION AND ACTING IN CONCERT Under the TAKeOver Bids Directive - 1ST UPDATE 2 (2014), https://www.esma.europa.eu/sites/default/files/library/2015/11/2014677.pdf [https://perma.cc/L66Z-CYHQ].

282. See id.

283. See Birkmose, supra note 174 , at 244.

284. EUROPEAN SEC. \& MKTS. AUTH., supra note 281, at 4 ("[W]here shareholders engaging in an activity on the White List are in fact cooperating with the aim of acquiring or exercising control over the company, or, in fact, have acquired or are exercising control, those shareholders will be regarded as persons acting in concert and may have to make a mandatory bid."). 
Similarly, the Market Abuse Regulation (MAR) deals with potential contrasts between shareholder engagement and the market abuse regime by observing that it "is not intended to prohibit discussions of a general nature regarding the business and market developments between shareholders and management concerning an issuer [because such] relationships are essential for the efficient functioning of markets and should not be prohibited." ${ }^{285}$ However, the Market Abuse Regulation does not provide an exemption for collective engagement or more detailed guidance on how to conduct engagement to avoid MAR infringements. ${ }^{286}$

Consequently, although the indications provided by European lawmakers and the ESMA could theoretically favor collective engagement by institutional investors, concerns remain because the current regulatory framework does not design an effective safe harbor for shareholder engagement. ${ }^{287}$ Therefore, should European lawmakers, regulators, and corporate governance experts consider that collective engagement can promote more effective involvement by active and passive institutional investors in the corporate governance of investee companies, a practical framework aimed at reducing collective engagement-related risks of violating disclosure and takeover rules and at favoring board-shareholder engagement should be developed.

In line with the objective, EU lawmakers-or the ESMA-could provide more detailed guidelines concerning concerted action by stating that collective engagement will not amount to concerted action where the institutional investors involved have signed a commitment not to form a concerted party or group seeking to obtain the control of the company that could trigger the mandatory bid threshold. Instead, lawmakers could encourage the appointment of a third party to monitor compliance with the agreement. Such a precaution is included in the Collective Engagement Framework of the Investor Forum, which provides that engagements are to be monitored by the Forum and involved institutional investors can be asked to leave or, if necessary, expelled from an engagement if their behavior compromises the collective initiatives. ${ }^{288}$ Along the same lines, to limit the threat of concerted action, stewardship codes could explicitly state that participating institutional investors who adhere to a collective engagement must refrain from any initiative aimed at seeking control of the relevant company.

285. Regulation 596/2014, of the European Parliament and of the Council of 16 April 2014 on Market Abuse (Market Abuse Regulation) and Repealing Directive 2003/6/EC of the European Parliament and of the Council and Commission Directives 2003/124/EC, 2003/125/EC and 2004/72/EC, 2014 O.J. (L 173) 1, 4.

286. See generally id.

287. See Birkmose, supra note 174, at 233-49, 252

288. INV'R FORUM, supra note 267, at 4. 
Likewise, to further promote collective engagements, EU lawmakers or the ESMA could provide more detailed guidance concerning topics that are more suitable for discussion or procedures that should be implemented to avoid infringements of market abuse rules within collective engagements. ${ }^{289}$ In designing such guidelines, the relevance of coordinating institutions such as the Investor Forum could be expressly recognized by admitting that they can help institutional investors to implement procedures aimed at preventing the abuse of inside information. ${ }^{290}$ Furthermore, corporate governance and stewardship codes should provide more detailed guidance concerning collective engagement by indicating how to avoid information leaks. In fact, until now, soft law guidance concerning collective engagement is, with some exceptions, quite generic and does not actually tackle the legal and practical problems posed by collective engagement. ${ }^{291}$

Neither regulatory approach would establish an absolute safe harbor. Judges and supervisory authorities might still take action against issuers and institutional investors based on alleged breaches of the takeover or market abuse legal framework. However, this could help promote collective engagement by providing institutional investors with more detailed guidelines and limiting the compliance costs associated with collective engagement.

\section{CONCLUSION}

Leading passive fund managers, such as the Big Three, which hold significant stakes in a large number of listed companies, perform an increasingly important corporate governance role and can also influence the conduct of activist shareholders. Although the Big Three vote at almost all shareholder meetings of investee companies and have made a significant

289. Strampelli, supra note 279 , at 240.

290. For the Collective Engagement Framework developed by the Investor Forum, see, for example, INV'R FORUM, supra note 267, at 3-4 (stating the Forum actively seeks to avoid the circulation of inside information and prevents institutional investors from participating in engagements and forming concert parties that would trigger the mandatory bid threshold).

291. See, e.g., EuropeAn Fund \& Asset MGMt. Ass'N, supra note 24, at 7 (“[W] hen participating in collective engagement [investors] should have due regard to market regulations and their own policies on conflicts of interest and insider information."); FIN. REPORTING COUNCIL, THE UK STEWARDShIP CODE 9 (2012), https://www.frc.org.uk/OurWork/Codes-Standards/Corporate-governance/UK-Stewardship-Code.aspx [https://perma.cc/ 7AXS-2UR6] ("Institutional investors should disclose their policy on collective engagement .... The disclosure should ... indicate the kinds of circumstances in which the institutional investor would consider participating in collective engagement."). 
number of engagements, it is still doubtful whether passive investors are indeed active owners because they have limited incentives to invest in stewardship. Anecdotal and empirical evidence provides limited conclusions but suggests passive investors tend to adopt a low-cost investment strategy to reduce costs associated with engagement with investee companies, thereby keeping their fees low. Therefore, because passive investors are focused on the long-term, the rise of passive investing provides confirmation that the main disincentive for engagement by passive and active institutional investors is not short-termism but cost.

Against this background, taking the current EU corporate governance framework as a reference, this Article has shown the limits to a regulatory approach to institutional shareholder engagement that mainly focuses on short-termism and argues that, to promote more effective institutional investor engagement, lawmakers, regulators, and corporate governance professionals should tackle cost-related issues more effectively. Moreover, the article has outlined a conceptual framework for possible regulatory strategies aimed at reducing the engagement-related costs that lawmakers could adopt to incentivize passive index funds managers and, more generally, nonactivist institutional investors to perform a more effective oversight role over investee companies. 